\title{
Basque nominalizations and the role of structural Case in the licensing of null arguments
}

\author{
Maia Duguine
}

\begin{abstract}
${ }^{\mathrm{i}}$
This article investigates the question of the licensing of null arguments in the so-called pro-drop languages. By focusing on the licensing of null subjects in the different types of $-\mathrm{T}(\mathrm{Z}) \mathrm{E}$ nominalizations in Basque, it aims at defining in a precise way the crucial feature that makes pro-drop possible in a clause. The central claim is that what licenses subject-drop is the assignment of structural Case. That is, it is argued that a subject can be null if and only if it is assigned structural Case. Different aspects of $\mathrm{T}(\mathrm{Z}) \mathrm{E}$ nominalizations are also explored, which show that even if these clauses are similar in the surface, they can be syntactically very different and furthermore, that infinitive clauses marked with the same nominalizing morpheme can also have diverging structures.
\end{abstract}

\section{Basque and the question of pro-drop}

The question of the licensing of null arguments is a longstanding problem in generative linguistics. Since the distribution of null arguments is not free cross-linguistically, the standard assumption is that their presence must be licensed (morpho-)syntactically ( $c f$. for instance the discussion in Holmberg 2005; cf. also Duguine 2012 for further arguments). However, the precise way in which this morphosyntactic condition must be stated is still not very clear. In the literature on pro-drop, the account of the licensing of null arguments is often based on the nature and the form of agreement morphemes, the idea being that 'rich agreement' can license subject-drop but 'poor agreement' cannot. In this system, English is assumed to be a poor agreement language and consequently, unable to license null subjects (1), whereas Spanish is considered to be a rich agreement language, which can license null subjects (2):

(1) $\mathrm{He} / *[\mathrm{e}]$ came.

English

(2) Él/[e] vino.

Spanish

he came.3sg

However, there is a whole set of languages that does not fit this classification: those languages where there is no agreement morphology and in which pro-drop is still possible. Japanese is one of them. As illustrated in (3), in Japanese a subject can be silent in the total absence of agreement morphology on the verb:

(3) [e] siken-ni otita.

exam-DAT failed

Japanese

'He/she failed the exam.'

In the literature, it is often assumed that pro-drop in languages like Spanish and pro-drop in languages like Japanese are different phenomena, and are therefore subject to different conditions (cf. for instance Holmberg \& Roberts 2010). However, as I argue in Duguine (2012), there is no empirical or conceptual reason for distinguishing two types of pro-drop. On the contrary, the null hypothesis is that there is a unique pro-drop phenomenon, a unique way to 
license null arguments cross-linguistically.

An argument against the hypothesis that there are two types of pro-drop languages and two different types of pro-drop is raised by pro-drop in languages like Basque. Basque has a SOV word order and is considered to be a discourse-configurational language. It also has a rich morphology. In particular, it has a three-way agreement system, where the inflected verb agrees in person and number with its ergative, absolutive and dative arguments. In finite clauses, this three-way agreement goes together with a three-way licensing of pro-drop. Thus, as illustrated in (4), the ergative, dative and absolutive arguments of a verb can be null in this language.

(4) Jonek/[e] Mireni/[e] itsasoa/[e] erakutsi dio. Jon.ERG Miren.DAT sea.ABS show AUX.3sgDAT.3sgaBS.3sgERG

Basque 'Jon showed the sea to Miren.'

Given the strict correspondence between the arguments that can be silent and those with which the verb agrees, it seems at first that Basque provides a strong argument in favor of the hypothesis that null arguments are licensed by agreement. What is interesting for our discussion, and raises a problem for the hypothesis that there are two different types of languages with respect to pro-drop, is that in Basque null arguments are also licensed in non-inflected clauses, in the total absence of inflectional morphology (Ortiz de Urbina 1983, 1989, Goenaga 1984, Oyharçabal 1991, Zabala \& Odriozola 1996, Elordieta 2002, Duguine 2008). ${ }^{\text {ii }}$ In this type of non-finite contexts, pro-drop in Basque strongly resembles pro-drop in Japanese.iii This is illustrated in (5). ${ }^{\text {iv }}$

(5) $[\mathrm{Jonek} /[\mathrm{e}]$ Mireni/[e] itsasoa/[e] erakus-te-a-k] Peio poztu du. Jon.ERG Miren.DAT sea.ABS show-TZE-D-ERG Peio.ABS please AUX 'That John showed the sea to Mary pleased Peio. (Lit. Jon showing the sea to Miren pleased Peio.'

Thus, Basque has both the Spanish-type of pro-drop and the Japanese-type of pro-drop. There are two ways to deal with this issue. Either we assume that two types of licensing for null arguments coexist in Basque (one for finite clauses and another for non-finite clauses); or we are forced to conclude that pro-drop is subject to a one and only condition in both types of contexts.

In this paper I argue that the analysis of pro-drop in Basque leads us to defend the view that there is a single type of pro-drop, and that null arguments are licensed in a unified way in both finite and non-finite contexts. If this is correct, the next step in the argumentation is obvious: the simplest hypothesis is that also at the cross-linguistic level, there is a unique type of pro-drop (for a more developed argumentation in this respect, $c f$. Duguine 2012). Under this view, a unified theory of pro-drop will have to account for the licensing of pro-drop both in contexts with and without agreement morphology, and both cross-linguistically and language internally. ${ }^{\mathrm{v}}$

But if our line of reasoning is on the right track and we assume that there is a single condition on pro-drop, we must conclude that this condition is not based on the richness of agreement, given that pro-drop is also licensed in languages (or contexts, in the case of Basque) without agreement. Here, I will propose an alternative to the standard analysis and argue that the licensing condition that regulates the distribution of null arguments should be stated as in (6): ${ }^{\text {vivii }}$

(6) Licensing Condition on Pro-Drop:

A DP can be elided iff its Case feature is valued structurally.

That is, the proposal I develop is that pro-drop is licensed only in positions in which the 
argument is assigned structural Case. In this article, I will argue in favor of (6) by studying the licensing conditions of null subjects in Basque infinitival clauses. The approach to the issue of the licensing of pro-drop that I propose here is original in that it is based on the study of the different degrees of (in)finiteness. As I mentioned above, in Basque null subjects are licensed in some infinitival clauses in the total absence of agreement features. However, as I will show below, not all infinitival clauses can have null subjects. Assuming that there is more than one way for a clause to be an infinitive -i.e. that infinitives can have different levels of structural complexity (cf. Wurmbrand 2001, Landau 2004, Adger 2007)-, the comparison between the different types of infinitives in Basque will make it possible to define the specific element (or, more precisely, the exact morphosyntactic feature) which licenses subject-drop. In this context, the study of Basque becomes specially relevant, since, as we will see, apart from being a massive pro-drop language, it also exhibits a rich variety of infinitives, which will allow us to develop a principled account of the variation in the licensing of pro-drop found in this type of uninflected clauses.

This paper is structured as follows. In section 2, I will first briefly introduce the different types of Basque nominalizations that will be the topic of the present study, and summarize their behavior with respect to the licensing of overt subjects. I will show that only certain types of nominalizations license overt subjects. Then, in section 3, I will present the paradigm of subject-drop in the different types of nominalizations. We will see that, unlike what is generally assumed, there is not a one-to-one correspondence between the licensing of overt subjects and the licensing of null subjects. Third, I will introduce my central proposal: I will argue that the licensing of pro-drop hinges on the assignment of structural Case and that it is precisely this feature that accounts for the distribution of null subjects in the different types of nominalizations in Basque (section 4). In section 5, I will discuss more facts on nominalizations that show that the correspondence between the different types of nominalizations and their Case-assignment properties is more complex than what meets the eye. In particular, we will see that what I refer to as 'argumental infinitives' in this paper can be the surface realization of structures with different levels of complexity. Finally, section 6 will summarize the main conclusions of the paper.

\section{Nominalization in Basque and the licensing of overt subjects}

In this section, I briefly introduce the syntax and morphology of the different types of nominalized clauses that we find in Basque, and summarize their behavior with regards to the possibility of licensing overt subjects.

Basque presents a wide variety of infinitival clauses (cf. Goenaga 1980, 1984, Ortiz de Urbina 1989, Artiagoitia 1995, 2003a, Trask 2003, San Martin \& Uriagereka 2002, San Martin 2004, this volume). In this work, I will limit myself to the study of what I will call 'T(Z)E infinitives' or 'T(Z)E nominalizations', because they surface with the morpheme -tze- or -teattached to the verb, and this morpheme has traditionally been analyzed as a nominalizing suffix. It is thus only to this type of infinitives that I will refer when talking about 'infinitives' in this article (cf. a.o. Goenaga (1984), Artiagoitia (1995, 2003a), Etxepare \& Uribe-Etxebarria (2009), Haddican (2009) for discussions on other types of infinitives). Following Artiagoitia (2003a), I will distinguish five different types of TZE nominalizations based on (i) their external syntax and (ii) their verbal morphology. In the following subsections I introduce each of these types and discuss their behavior with regards to the licensing of overt subjects.

One comment before we begin. Given that we are studying infinitives, we will confront different types of non-overt subjects. This is why the notion of 'non-overt subject', that I will be using here, should not be confused with that of 'null subject' or with that of 'silent controlled subject'. In this paper, 'null subjects' refer to the silent, referential subjects found in pro-drop 
languages, and traditionally referred to as pro (represented as $[e]$ in the examples) and 'silent controlled subjects' refer to the unpronounced subjects of non-finite clauses, whose interpretation is dependent on a local c-commanding antecedent, and which can be either PROs or NP-traces in traditional syntax. In turn, the notion 'non-overt subject' is a descriptive notion that refers to a subject position which is not occupied by an overt subject (represented as $\Delta$ in the examples below), and hence embraces both null subjects and silent controlled subjects. ${ }^{\text {viii }}$

\subsection{Nominalized clauses in argument position: Argumental infinitives}

The nominalized clauses I will refer to as 'argumental infinitives' here are those TZE infinitives that behave as arguments of the predicate in the main clause. Thus, they can be subjects, direct objects or indirect objects and are morphologically case-marked accordingly (i.e. they surface with ergative, absolutive or dative case attached to the $-t(z) e$ suffix). These three types of argumental infinitives are illustrated in (7), (8) and (9) respectively. ${ }^{\text {ix }}$

(7) a. [Haurr-ek liburuak irakurtze-a-k] pozten gaitu.

children-ERG books.ABS read-TZE-D-ERG delight AUX.1plABS.3sgERG

'It delights us that the children read books.'

b. [Haurrak joa-te-a-k] pozten gaitu.

children.ABS go-TZE-D-ERG delight AUX.1plABS.3sgERG

'It delights us that the children leave.'

(8) a. [Haurr-ek irakurtze-a-ri] lehentasuna eman diogu.

children-ERG read-TZE-D-DAT priority.ABS give AUX.3sgABS.1pleRG.3sgAB

S

'We gave the priority to the children's reading.'

b. [Haurrak joa-te-a-ri] lehentasuna eman diogu.

children.ABS go-TZE-D-DAT priority.ABS give AUX.3sgABS.1plERG.3sgABS

'We gave the priority to the children's leaving.'

(9) a. Begi onez ikusten dugu [haurr-ek irakur-tze-a].

favorably see AUX.3sgABS.1pleRG children-ERG read-TZE-D.ABS

'We see favorably that the children read.'

b. Begi onez ikusten dugu [haurrak joa-te-a].

favorably see AUX.3sgABS.1pleRG children.ABS go-TZE-D.ABS

'We see favorably that the children leave.'

As can be seen in all the examples, overt subjects are allowed with all three different types of argumental infinitives. The ergative, dative and absolutive infinitives in (7), (8) and (9) license ergative subjects as well as absolutive subjects, as illustrated in the (a) and (b) examples, respectively.

\subsection{Nominalized clauses as adjuncts: Infinitival adjuncts}

The second type of TZE nominalization is formed by infinitival adjuncts. It is characterized by the fact that a postposition attaches to the morpheme -tze- (with a determiner inserted between the two, in some cases). The morphological make up, then, is as follows: [ ... V-t(z)e-(Det)-P].

The examples in (10)-(12) illustrate some of the postpositions that can attach to the infinitival clause. As illustrated in (12), infinitive adjuncts can also be adnominal modifiers (cf. Oyharçabal 1998).

(10) [Negua etor-tze-a-rekin], enarak badoaz

(Goenaga 1980: 322) 
winter.ABS come-TZE-D-with swallows.ABS go.3plABS

'With the coming of the winter, the swallows leave.'

(11) [Zuk kanta-tze-a-n], arazo guztiak ahazten ditut. you.ERG sing-TZE-D-INE problem all.ABS forget AUX 'When you sing, I forget all my problems.'

(12) [Zuek hemendik joa-te-ko] ordua da. you(pl).ABS here.from go-TZE-for time AUX 'It is time for you to leave.'

As can be seen in these examples, overt subjects (ergative and absolutive) are also licensed in this type of nominalizations.

The three remaining types of TZE infinitives are complements of specific verbs. What distinguishes them from one another is their morphology and the type of verb they can be the complements of. I present them in the next three subsections.

\subsection{Nominalized clauses as infinitival complements of directive verbs (V-t(z)eko)}

First, we have the TZE infinitivals that can be complements of directive verbs like agindu 'order', eskatu 'ask' or esan 'say':
(13) $[\mathrm{Zu}$ etxera joa-teko] esan/agindu/eskatu didate. you.ABS home.to go-TZEKO say/order/ask AUX.3sgABS.1sgDAT.3pleRG Lit. 'They told/ordered/asked me you to go home.'

As illustrated in (13), the complements of directive verbs are all headed by the morpheme -t(z)eko (see footnote 9). As (13) also shows, the infinitival complements of directive verbs can license overt subjects (both ergative and absolutive).

\subsection{Nominalized clauses as infinitival complements of verbs of motion (V-t(z)era)}

Another type of infinitival complement is the one that typically appears as a complement of verbs of motion such as joan 'go', etorri 'come', igorri or bidali 'send', or to verbs like behartu 'force'. These complements are headed by the morpheme $-t(z) e r a .{ }^{x}$

(14) $\mathrm{Ni}_{\mathrm{i}} \quad\left[\Delta_{\mathrm{i}} / *\right.$ Mirenek lan egi-tera $]$ joan naiz.

I.ABS Miren.ERG work do-TZERA go AUX.1sgABS

'I am going (*Miren) to work.'

As illustrated in (14), these complements cannot license an overt subject. ${ }^{\mathrm{xi}}$ The subject must be non-overt and furthermore it must be controlled by a DP in the main clause.

\subsection{TZEN complements ( $\mathrm{V}-\mathrm{t}(\mathrm{z}) \mathrm{en})$}

The last type of $\mathrm{T}(\mathrm{Z}) \mathrm{E}$ nominalized clause is the one headed by the morpheme $-t(\mathrm{z}) e n$. TZEN infinitives can be selected by semiauxiliary verbs (15) (cf. Laka 2006), aspectual verbs (16), verbs of knowledge (17), perception verbs (18) ( $c$. Arteatx (this volume)), and triadic verbs like utzi 'let' (19), or saiatu 'try' (20) (cf. Artiagoitia (2003a) for a more precise overview). ${ }^{\text {xii }}$

(15) $\operatorname{Jon}_{\mathrm{i}} \quad\left[\Delta_{\mathrm{i}} / *\right.$ Mirenek lan egi-ten $]$ ari da. Jon.ABS Miren.ERG work do-TZEN PROG AUX.3sgABS 
'Jon is (*Miren) working.'

(16) $\operatorname{Jon}_{\mathrm{i}} \quad\left[\Delta_{\mathrm{i}} / *\right.$ Mirenek lan egi-ten $]$ hasi da.

Jon.ABS Miren.ERG work do-TZEN begin AUX.3sgABS

'Jon has begun (*Miren) to work.'

(17) Jonek $_{\mathrm{i}}\left[\Delta_{\mathrm{i}} / *\right.$ Mirenek lan egi-ten $]$ daki.

Jon.ERG Miren.ERG work do-TZEN know.3sgABS

'Jon knows (*Miren) working.'

(18) $\operatorname{Jon}_{\mathrm{i}} \quad\left[\Delta_{\mathrm{i}} / *\right.$ Mirenek lan egi-ten $]$ ikusi dugu.

Jon.ABS Miren.ERG work do-TZEN see AUX.3sgABS.3sgerG

'We saw Jon (*Miren) working.'

(19) $\operatorname{Jon}_{\mathrm{i}} \quad\left[\Delta_{\mathrm{i}} / *\right.$ Mirenek lan egi-ten $]$ utzi dugu.

Jon.ABS Miren.ERG work do-TZEN leave AUX.3sgABS.3sgerG

'We let Jon (*Miren) working.'

(20) $\operatorname{Jon}_{\mathrm{i}} \quad\left[\Delta_{\mathrm{i}} / *\right.$ Mirenek lan egi-ten $]$ saiatu da.

Jon.ABS Miren.ERG work do-TZEN try AUX.3sgABS

'Jon tried (*Miren) to work.'

As illustrated above, with none of these verbs can the TZEN complement have an overt subject internal to the nominalized clause. ${ }^{\text {xiii }}$

Summarizing, we have seen that there are five types of TZE infinitives, or nominalizations, that differ from each other with respect to the verbal morphology (i.e. the morphemes that attach to -tze) as well as with respect to the syntactic role they play in the main clause. We have seen that these five types of nominalizations can be divided into two groups with regards to the possibility of licensing overt subjects. On the one hand, overt subjects are licensed in argumental infinitives, infinitival adjuncts and in the infinitival complements of directive verbs. On the other hand, overt subjects are not licensed within infinitival complements of motion verbs and within TZEN infinitival complements ( $c f$. also Goenaga 1984, Ortiz de Urbina 1989, San Martin \& Uriagereka 2002, San Martin 2004). In the following section, I will show that not all nominalizations that license overt subjects can also license null subjects (unlike what is generally assumed in the literature; see for instance Ortiz de Urbina (1989)).

\section{Subject-drop in nominalizations}

Recall that the goal of this paper is to define the specific feature which is crucial for the licensing of null subjects by studying the differences between uninflected clauses that do license null subjects and those that do not. Before we begin, we must thus first define what a null subject is in opposition to other types of non-overt subjects we may find in a clause.

Null subjects, traditionally referred to as pros, are viewed as the silent counterpart of pronouns ( $c f$. Chomsky 1982). They are in consequence referential and they can be free in their binding domain. But it is also well-known that there exist other types of phonologically non-overt subjects. In traditional terminology, they are referred to as PROs and NP-traces (cf. Chomsky 1982). PROs and traces can typically appear in non-finite clauses, as illustrated in the English examples in (21): $:^{\mathrm{xiv}, \mathrm{xv}}$

(21) a. Controlled PRO:

$\mathrm{John}_{\mathrm{i}}$ wants $\left[\mathrm{PRO}_{\mathrm{i} / * \mathrm{j}}\right.$ to leave].

b. NP-trace of raising:

$\mathrm{John}_{\mathrm{i}}$ seems [ $\ldots \mathrm{i}_{\mathrm{i} /{ }_{\mathrm{j}}}$ to be $\left.\mathrm{sad}\right]$. 
As can be seen in (21), the interpretation of both PRO and NP-trace depends on the interpretation of a c-commanding DP in a higher clause. As far as we are concerned in this paper, then, PROs and NP-traces are basically the same type of elements, because they share a feature that distinguishes them from pro: their interpretation is not free. ${ }^{\text {xvi }}$ For the sake of the argument, we will therefore group PROs and NP-traces together, as they both are 'controlled non-overt subjects'. xvii

As I said above, controlled non-overt subjects usually appear in non-finite contexts. Now, given that our objects of study are the nominalized non-finite clauses in Basque, it is important that we can tease apart actual null subjects from these non-overt controlled subjects. In fact, we can achieve this goal by simply looking at the interpretation of the non-overt subject in question: if it is not obligatorily controlled, then it is a null subject, and if its interpretation is not free, then it is a controlled non-overt subject.

In this section, I study the properties of the non-overt subjects we find in the different types of nominalizations described in section 2. I begin with the complements of motion verbs and TZEN complements where, as we saw above, overt subjects are not licensed.

\subsection{No null subject in clauses that do not license overt subjects}

We saw above that overt subjects are not licensed inside infinitival complements of motion verbs and TZEN complements (sections 2.4 and 2.5). As is illustrated in the examples below, null subjects are not licensed either in these infinitives. The only possible reading for the non-overt subject is a reading in which it is controlled by a higher DP. This is the case in the TZERA complement of the motion verb in (22), as well as in the two examples of TZEN complements that follow: in the complement of the aspectual verb hasi 'begin' in (23), and in the complement of the perception verb ikusi 'see' in (24):

(22) $\mathrm{Ni}_{\mathrm{i}} \quad\left[\Delta_{\mathrm{i}^{*} \mathrm{j}}\right.$ lan egi-tera $]$ noa.

I.ABS work do-TZERA go.1sgABS

'I am going to work.'

(23) $\operatorname{Jon}_{\mathrm{i}} \quad\left[\Delta_{\mathrm{i} /{ }^{*} \mathrm{j}}\right.$ lan egi-ten $]$ hasi da. Jon.ABS work do-TZEN begin AUX.3sgABS

'Jon has begun to work.'

(24) Guk $\operatorname{Jon}_{\mathrm{i}}\left[\Delta_{\mathrm{i} / *_{\mathrm{j}}}\right.$ lan egi-ten $]$ ikusi dugu.

we.ERG Jon.ABS work do-TZEN see AUX.3sgABS.3sgERG

'We saw Jon working.'

In none of these cases can the non-overt subject have a free interpretation. We must thus conclude that the non-overt subjects we find in both infinitival complements of motion verbs and TZEN complements are controlled non-overt subjects (i.e. in traditional terms, they are either PROs or NP-traces). In the following section, we will study the nominalizations in which overt subjects are licensed, i.e. in argumental infinitives, infinitive adjuncts and complements of directive verbs.

\subsection{Variation in clauses that license overt subjects}

As we will see in this section, not all types of infinitives in which overt subjects are licensed show the same behavior with regards to the licensing of null subjects.

On the one hand, the subject of argumental infinitives can be freely dropped, whatever the grammatical function of the clause is (I represent the null subject with $[e]$ ): ${ }^{\text {viii }}$ 
(25) [[e] liburuak irakur-tze-a-k] pozten ditu. books.ABS read-TZE-D-ERG delight AUX.3plaBs.3sgERG

'It delights them that I/you/he/she/we/they read books.'

(26) [[e] liburuak irakur-tze-a-ri] lehentasuna eman diote. books.ABS read-TZE-D-DAT priority.ABS give AUX.3sgABS.3plERG.3sgABS 'They gave the priority to my/your/her/his/their reading of books.'

(27) Begi onez ikusten dute favorably see AUX.3sgABS.3pleRG books.ABS read-TZE-D.ABS 'They see favorably that I/you/he/she/we/they read books.'

As illustrated in the English translations, the interpretation of the non-overt subjects is not controlled by that of higher DPs. In consequence, they are null subjects, i.e. they are what are traditionally named pros.

Thus, we can see that while in the nominalized clauses in which overt subjects are never licensed, null subjects are not licensed either (section 3.1), null subjects are licensed in argumental infinitives. That is, for a clause to be able to license null subjects, it must also be able to license overt subjects. However, as we will see now, even if this condition is necessary, it is not sufficient, given that null subjects are not licensed in other nominalizations in which overt subject DPs are licensed.

Null subjects are not licensed in complements of directive verbs (28b) or in infinitival adjuncts (29b)-(30b): ${ }^{\text {ix }}$

(28) a. Niri $i_{i}$ [haurrak ixilik ego-teko] agindu zidan. me.DAT children.ABS silent stay-TZEKO order AUX.1sgDAT.3sgERG Lit. 'She ordered me the children to remain silent.'

b. Niri $_{\mathrm{i}}\left[\Delta_{\mathrm{i} / * \mathrm{j}}\right.$ ixilik ego-teko $]$ agindu zidan. me.DAT silent stay-TZEKO order AUX.1sgDAT.3sgERG 'She ordered me to remain silent.'

(29) a. [Zuk kanta-tze-a-n] $\mathrm{ni}_{\mathrm{i}}$ beti alaitzen naiz. you.ERG sing-TZE-D-INE I.ABS always cheer.up AUX.1sgABS 'When you sing I always cheer up.'

b. $\left[\Delta_{\mathrm{i} / *_{\mathrm{j}}}\right.$ kanta-tze-a-n] $\mathrm{ni}_{\mathrm{i}}$ beti alaitzen naiz. sing-TZE-D-INE I.ABS always cheer.up AUX.1sgABS

'When I sing I always cheer up.'

(30) a. [Zu borroka-tze-a-gatik] zigortu gaituzte denak . $_{\text {. }}$ you.ABS fight-TZE-D-because punish AUX.3sgABS.3plERG all 'They punished us all because you fought.'

b. $\left[\Delta_{\mathrm{i} / * \mathrm{j}}\right.$ borroka-tze-a-gatik $]$ zigortu gaituzte denak $\mathrm{k}_{\mathrm{i}}$. fight-TZE-D-because punish AUX.3sgABS.3pleRG all

'They punished us all because we fought.'

As shown by the indexing, the silent subjects inside the infinitives cannot have a free reading (their reading obligatorily covaries with that of a higher DP). This is in consequence what we called a 'controlled non-overt subject', and not a null argument, despite the fact that it can have an overt counterpart.

Summarizing, (non-controlled) null subjects can only be licensed within argumental infinitives. ${ }^{\mathrm{xx}}$ The typology of TZE infinitives with respect to the licensing of overt and null subjects is given in the table below.

(31) Table 1. Licensing of overt and null subjects in Basque TZE nominalizations 


\begin{tabular}{|c|c|c|c|c|c|}
\hline & $\begin{array}{c}\text { Argumental } \\
\text { infinitives }\end{array}$ & $\begin{array}{c}\text { Infinitival } \\
\text { adjuncts }\end{array}$ & $\begin{array}{c}\text { Complements } \\
\text { of directive } \\
\text { verbs (TZEKO) }\end{array}$ & $\begin{array}{c}\text { Complements of } \\
\text { verbs of motion } \\
\text { (TZERA) }\end{array}$ & $\begin{array}{c}\text { TZEN } \\
\text { complements }\end{array}$ \\
\hline Overt subject & $\checkmark$ & $\checkmark$ & $\checkmark$ & $\mathbf{x}$ & $\mathbf{x}$ \\
\hline Null subject (pro) & $\checkmark$ & $\mathbf{x}$ & $\mathbf{x}$ & $\mathbf{x}$ & $\mathbf{x}$ \\
\hline
\end{tabular}

As we said above, it is crucially only when overt subjects are licensed that null subjects can also be licensed. However, this is not a sufficient condition, given that null subjects are not licensed in infinitival adjuncts and in the complements of directive verbs, two contexts where overt subjects are allowed within the uninflected clause.

But this also means that we have uncovered a contrast that will be crucial for understanding what the precise morphosyntactic condition is that accounts for the licensing of null arguments: we now have a minimal pair between infinitival clauses in which subjects can be dropped and infinitival clauses in which they cannot. And if these infinitives constitute a minimal pair with respect to subject-drop, then they also constitute a minimal pair with respect to the syntactic condition on which pro-drop depends.

In consequence, a detailed analysis of the minimal morphosyntactic difference that distinguishes these two uninflected clauses from each will help us find what the exact morphosyntactic condition on the licensing of null subjects is. In the next section, I will argue that this difference (and thus the condition on the licensing of null subjects) is the assignment of structural Case to the subject.

\section{Assignment of structural Case to subjects}

Argumental infinitives, infinitival adjuncts and complements of directive verbs are all similar in that they are TZE nominalizations in which overt subjects are licensed, but they differ in the licensing of null subjects: these are licensed in argumental infinitives only (recall that PROs and NP-traces are not null subjects, but controlled non-overt subjects). There is in consequence a minimal syntactic difference between the different types of nominalizations which is crucial for the licensing of null subjects. That is, the condition for pro-drop is satisfie in the first but not in the other two.

In this section, I argue that the syntactic difference between both types of infinitives is that the subject is assigned structural Case in argumental infinitives but not in the complement of directive verbs or infinitival adjuncts, and that it is precisely the assignment of structural Case that is a necessary condition for the licensing of null arguments. In particular, I want to put forth the following licensing condition on null arguments: ${ }^{\text {xxi }}$

(32) Licensing Condition on Pro-Drop:

A DP can be elided iff its Case feature is valued structurally.

If (32) is right, it means that in Basque argumental infinitives, the (uninflected) inflectional head $\mathrm{T}$ assigns structural Case to the subject of the clause, whereas in other types of nominalizations, it does not (or there is no T). ${ }^{\text {xii,xxiii }}$ Note that this implies that within infinitival adjuncts and complements of directive verbs, even when the subject is overt, it is not assigned structural Case. ${ }^{\text {xxiv }}$

In this section, I argue in favor of (32), by giving evidence that shows that argumental infinitives, on the one hand, and infinitival adjuncts and complements of directive verbs, on the other hand, differ with respect to structural Case assignment to the subject. First, I give a 
conceptual argument in favor of (32). Constructions with PROs or NP-traces, on the one hand, and constructions with null subjects, on the other hand, are in complementary distribution. In consequence, if we assume that control/raising structures are constructions in which Case is not assigned to the subject within the embedded clause, (32) can only be right (section 4.1). Then, I discuss the Obligatory Control (OC) vs. Non Obligatory Control (NOC) properties of the different types of constructions, showing that they tease apart the different types of nominalizations just in the way predicted if (32) is right (section 4.2). Third, in section 4.3, I give evidence from floating quantifiers that shows that the differences among the different types of nominalizations with respect to case-assignment to subjects are just as predicted by (32). Finally, in section 4.4, I show how data from the extraction of subjects out of nominalizations indicates that the subjects only get case in those nominalizations in which subjects can also be null.

\subsection{No null arguments without structural Case}

The licensing condition on pro-drop in (32) predicts that null arguments will not be allowed in non-structural Case positions. As we saw above, the only type of silent subject that we find in cases in which null subjects are not licensed are controlled non-overt subjects. This is illustrated below, with an adjunct (33), a complement of directive verb (34), a complement of motion verb (35) and a TZEN complement (36):

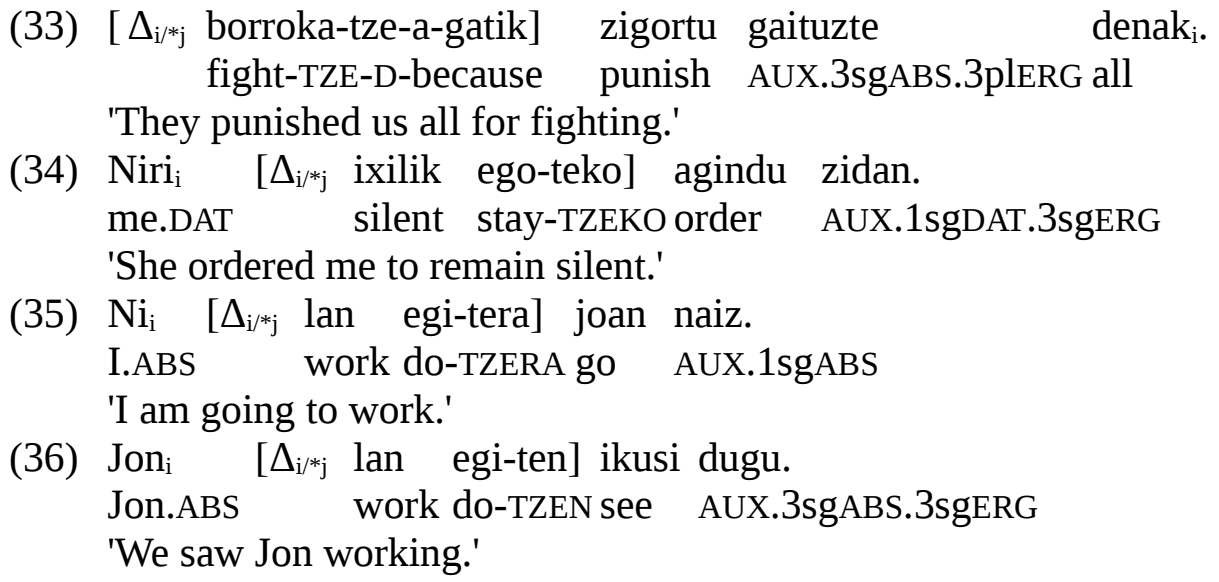

Are these silent subjects in non-Case positions? In the literature, given their controlled interpretation, they have been subsumed under the theory of control and/or raising, i.e., they have been analyzed as PROs (cf. Goenaga (1984), Ortiz de Urbina (1989), San Martin $(2000,2004)$ for various instances of this type of approach) or as traces of raised DPs (Arteatx (this volume)). Now, control and raising both involve structures where structural Case is not assigned to the subject (cf. Bouchard 1984, Chomsky 1986, Hornstein 1999). This means that in infinitive adjuncts and all three types of infinitive complements illustrated in (33)-(36), no structural Case is assigned to the subject inside the infinitival clause. Also, it means that in argumental infinitives, which are not constructions with controlled or raised subjects, the subject in fact receives structural Case internal to the infinitival clause. Crucially, this is completely parallel to the predictions made by (32), i.e. that null arguments will be licensed only in contexts in which structural Case is assigned.

In sum, if the theory of control/raising and the theory of null arguments spelled-out in (32) represent the two sides of structural Case assignment (i.e. the cases in which structural Case is assigned vs. the cases in which it is not), then we also expect that the elements they each govern -i.e. PRO/NP-traces and null arguments- will be in complementary distribution. And this prediction is in fact borne out, given that we find null arguments only in argumental infinitives, 
and PROs and/or raised DPs only in infinitival adjuncts, complements of directive verbs, complements of motion verbs and TZEN complements.

Of course, this raises the issue of the status of overt subject. If the analysis that I propose is right, it implies that the overt subjects which are licensed in argumental infinitives and infinitival adjuncts -in examples such as (28a), (29a) and (30a) above- are not assigned structural Case, unlike what is generally assumed in the literature. However, I don't think this has to be taken as an unwelcome result. First of all, even if it is widely assumed that cross-linguistically subjects are always assigned structural Case, this assumption has no obvious conceptual basis. Furthermore, if, as suggested in Chomsky (2000), the assignment of structural Case or the syntactic licensing of an overt DP does not directly determine the morphophonological realization of the DP (cf. also Schütze 1997, Marantz 2000, Pesetsky \& Torrego 2004), then it is possible that not all DPs surfacing with the same morphological case-marker are assigned structural Case. In other words, it is in principle conceptually possible that not all ergative- or absolutive-marked subjects are assigned structural Case in Basque.

Also, there have been shown to exist cross-linguistically many instances where OC alternates with an overt subject in the exact same syntactic context. For instance, Pires (2007) argues that the structure of the clausal gerunds in the English examples in (37) and (38) is the same, i.e. that they have the same feature specification:

(37) Susan preferred [PRO being late for dinner].

(38) Susan preferred [John/him being late for dinner].

Many Romance languages also allow overt subjects in non-finite constructions (cf. Mensching 2000), and the coexistence of OC PRO and overt subjects is also known to exist in languages like Irish (McCloskey 1985), Greek (Sitaridou 2002), or West Flemish (Haegeman 1985). That is, in the contexts at hand, overt subjects do not alternate with null arguments, but with controlled non-overt subjects. Similarly, Sundaresan \& McFadden (2009) give examples from a broad number of other languages where OC PRO and overt subject DPs freely alternate in certain constructions: Tamil, Malayalam. Sinhala, Latin, Middle English. They argue that 'the fundamental prediction made by Case theory, namely that obligatorily controlled PRO and overt DPs are in complementary distribution, is not empirically justified'. From our point of view, in fact, and taking our licensing condition on pro-drop, the prediction is that it is obligatorily controlled PRO and null subjects that will be in complementary distribution.

\subsection{Types of control}

Control constructions have been divided into two types: Obligatory Control (OC) and Non-Obligatory Control (NOC) ( $c$. Williams 1980). Many diagnostic tests show that in fact the silent subject has a different behavior with regards to its interpretation in OC and NOC constructions (these tests are gathered in Hornstein 1999). In this section, I apply these tests to the structures under analysis and show that argumental infinitives must be classified together with finite clauses, where structural case is assigned to the subject. The tests will also show that, in contrast, infinitival adjuncts and complements of directive verbs behave like those infinitival complements which do not license overt DP subjects and always have a controlled subject reading.

As illustrated below, in Basque, the subject can be null and coreferent with a DP in the higher clause in argumental infinitives (39), in complements of directive verbs (40) and in infinitive adjuncts (41) (cf. also Ortiz de Urbina 1989, San Martin 2004):

(39) Jonek $_{\mathrm{i}}\left[\Delta_{\mathrm{i}}\right.$ irakur-tze-a-ri $]$ lehentasuna ematen dio. 
Jon.ERG read-TZE-D-DAT priority give AUX

'Jon gives the priority to reading.'

(40) Nik Joni $\mathrm{i}_{\mathrm{i}}\left[\Delta_{\mathrm{i}}\right.$ irakur-tzeko] agindu diot.

I.ERG Jon.DAT read-TZEKO order AUX

'I ordered Jon to read.'

(41) $\operatorname{Niri}_{\mathrm{i}}\left[\Delta_{\mathrm{i}}\right.$ autoan irakur-tze-a-gatik] isuna jarri didate.

I.DAT car.in read-TZE-D-because fine put AUX

'I got a ticket because of reading in the car.'

However, even if the three constructions look alike from the point of view of the interpretation of the embedded subject, the diagnostic tests for distinguishing OC from NOC show that they are deeply different. But what is important for us is that they also show that argumental infinitives pattern together with finite clauses whereas complements of directive verbs and infinitive adjuncts always pattern together with those infinitives which do not license any overt subjects internally. ${ }^{\mathrm{xxv}, \mathrm{xxvi}}$

\subsubsection{Long distance antecedent}

In OC constructions, the antecedent of the controlled subject cannot be higher than the immediately higher clause, whereas in those cases involving NOC, the non-overt subject can take its antecedent across more than one single clausal boundary (that is, its antecedent can be several clauses higher). This is illustrated with English in (42) and (43) respectively: ${ }^{\text {xxvii }}$

(42) $* \mathrm{John}_{\mathrm{j}}$ thinks [that it was expected [ $\Delta_{\mathrm{j}}$ to shave himself]].

(43) $\mathrm{John}_{\mathrm{i}}$ thinks [that it is believed that [[ $\Delta_{\mathrm{i}}$ shaving himself] is important].

As the examples below show, if we apply this test to Basque, we find two types of behavior. On the one hand, in finite clauses (44) and argumental infinitives (45), the antecedent of the null subject can be nonlocal:

(44) Mirenek $_{\mathrm{i}}$ badaki [Jonek [ $\Delta_{\mathrm{i}}$ bakarrik egon behar duela] esan duela]. Miren.ERG know Jon.ERG alone stay need AUX.that say AUX.that

'Miren knows that Jon said that she needs to stay alone.'

(45) Mirenek $_{\mathrm{i}}$ badaki [Jonek [ $\Delta_{\mathrm{i}}$ bakarrik ego-te-a] nahi duela]. Miren.ERG know Jon.ERG alone stay-TZE-D.ABS want AUX.that 'Miren knows that Jon wants her to stay alone.'

And on the other hand, in complements of directive verbs (46) and infinitival adjuncts (47) the antecedent cannot be nonlocal.

(46) Mirenek $_{\mathrm{i}}$ badaki [Jonek [ $\Delta_{*_{\mathrm{i}}}$ bakarrik ego-teko] esan digula]. Miren.ERG know Jon.ERG alone stay-TZEKO say AUX.that 'Miren knows that Jon told us her to stay alone.'

(47) Mirenek $_{\mathrm{i}}$ badaki [Jon [ $\Delta_{*_{\mathrm{i}}}$ lana buka-tze-a-n] etorriko dela]. Miren.ERG know Jon.ABS work finish-TZE-D-INE come AUX.that 'Miren knows that Jon will come after she finishes the work.'

This is also what happens with the other types of complements, that is, complements of motion verbs (48) and TZEN complements (49).

(48) Mirenek $_{\mathrm{i}}$ badaki [Jon [ $\Delta_{*_{\mathrm{i}}}$ lana buka-tzera] etorriko dela]. 
Miren.ERG know Jon.ABS work.ABS finish-TZERA come AUX.that 'Miren knows that Jon will come (for) her to finish the work.'

(49) Mirenek $_{\mathrm{i}}$ badaki [Jon [ $\Delta_{*_{\mathrm{i}}}$ lana buka-tzen] ikusi dutela]. Miren.ERG know Jon.ABS work.ABS finish-TZEN see AUX.that 'Miren knows that they saw Jon her finishing the work.'

That is, argumental infinitives behave like finite clauses with respect to the interpretation of non-overt subjects -i.e. like clauses in which subjects are assigned structural Case-, whereas the complements of directive verbs and the infinitival adjuncts behave like the complements cannot license an overt subject -i.e. like clauses in which subjects cannot be assigned structural Case.

\subsubsection{C-command}

Another distinguishing property of OC vs. NOC is the necessity for the antecedent to be in a c-commanding position. As illustrated below with English, OC PRO needs a c-commanding DP (50), while this is not necessary for NOC PRO (51):

(50) $* \mathrm{John}_{\mathrm{i}}$ 's campaign expects [ $\Delta_{\mathrm{i}}$ to shave himself].

(51) Clinton ${ }_{\mathrm{i}}$ 's campaign believes that [ $\Delta_{\mathrm{i}}$ keeping his sex life under control] is necessary for electoral success.

As in the English example in (51), in Basque the null subject can have a non-c-commanding antecedent in finite clauses (52) and argumental infinitives (53):

(52) $\left[\right.$ Mirenen $_{\mathrm{i}}$ anaiak] badaki [ $\Delta_{\mathrm{i}}$ bakarrik egon behar duela]. Miren.GEN brother.ERG know alone stay need AUX.that 'Miren's brother knows she needs to stay alone.'

(53) $\left[\right.$ Mirenen $_{\mathrm{i}}$ anaiak] badaki $\left[\Delta_{\mathrm{i}}\right.$ bakarrik ego-te-a] beharrezkoa dela. Miren.GEN brother.ERG know alone stay-TZE.D.ABS necessary AUX.that 'Miren's brother knows that he staying alone is necessary.'

On the contrary, in infinitive adjuncts (54), verbal complements of directive verbs (55), complements of motion verbs (56) and TZEN complements (57), the antecedent needs to be in a c-commanding position with regards to the controlled subject:

(54) Mirenen $_{\mathrm{i}}$ anaia joan da, $\left[\Delta_{*_{\mathrm{i}}}\right.$ bakarrik ego-te-ko]. Miren.GEN brother.ABS go AUX alone stay-TZE-for 'Miren's brother left for her to stay alone.'

(55) $\left[\right.$ Mirenen $_{\mathrm{i}}$ anaiari $] \quad\left[\Delta_{*_{\mathrm{i}}}\right.$ bakarrik ego-teko $]$ esan diote. Miren.GEN brother.DAT alone stay-TZEKO say AUX 'They told Miren's brother her to stay alone.'

(56) $\left[\right.$ Mirenen $_{\mathrm{i}}$ anaia] $\left[\Delta_{*_{\mathrm{i}}}\right.$ bakarrik lan egi-tera] bidali dute. Miren.GEN brother.ABS alone work do-TZERA send AUX 'They sent Miren's brother for her to work alone.'

(57) $\left[\right.$ Mirenen $_{\mathrm{i}}$ anaia] $\left[\Delta_{*_{\mathrm{i}}}\right.$ bakarrik lan egi-ten] hasi da. Miren.GEN brother.ABS alone work do-TZEN begin AUX 'Miren's brother began her to work alone.'

\subsubsection{Strict reading}

A third diagnostic test to tease apart OC from NOC is that of the variability in the interpretation 
of the non-overt subject under ellipsis. This is illustrated in (58)-(59).

(58) $\mathrm{John}_{\mathrm{i}}$ expects [ $\Delta_{\mathrm{i}}$ to win] and Bill does too.

(59) $\mathrm{John}_{\mathrm{i}}$ thinks that $\left[\Delta_{\mathrm{i}}\right.$ getting his résumé in order] is crucial and Bill does too.

The first conjunct in (58) has a control interpretation. What is important is that the interpretation of the second conjunct, where the control structure has been elided together with the VP, is the one that corresponds to a sloppy interpretation, i.e. the reading 'Bill expects himself to win' is the only possible reading, since the strict reading 'Bill expects John to win' is not available. In contrast, in the case of an elided NOC PRO, both the sloppy and the strict reading are possible. For instance, with a NOC PRO such as the one in (59), the second coordinate can either be interpreted as 'Bill thinks that Bill getting his resumé in order is crucial' (sloppy reading) or 'Bill thinks that John getting his resumé in order is crucial' (strict reading).

Turning now to ellipsis in Basque nominalizations, what we find is that the strict reading of the embedded subject (i.e. the one in which it is co-referential with the subject Miren of the first sentence), is perfectly available both in finite clauses (60) and in argumental infinitives (61). That is, the second sentence in (60) and (61) can be interpreted as 'Peio knows they want Miren to leave the job, too'.

(60) Mirenek $k_{\mathrm{i}}$ badaki [ $\Delta_{\mathrm{i}}$ lana utz dezan] nahi dutela. Eta Peiok ere. Miren.ERG know work.ABS leave AUX.C want AUX.thatand Peio.ERG too 'Miren knows they want her to leave the job. And Peio does too.' strict $\checkmark$

(61) Mirenek $_{\mathrm{i}}$ badaki $\left[\Delta_{\mathrm{i}}\right.$ lana uz-te-a] nahi luketela. Eta Peiok ere. Miren.ERG know work.ABS leave-TZE-D-ABS want AUX.thatand Peio.ERG too 'Miren knows they want her to leave the job. And Peio does too.' strict $\checkmark$

On the other hand, the strict reading is not available in cases involving ellipsis of infinitive adjuncts, or complements of directive verbs, as in the case of complements of verbs of motion and TZEN complements. That is, (i) the reading 'Peio gets scared when Miren is alone' is not available for the the second sentence containing an infinitival adjunct in (62), (ii) the interpretation 'They told Peio that Miren must stay alone, too' is not available with the complement of the directive verb in (63), (iii) the interpretation 'They forced Peio to a situation in which Miren would remain alone, too' is not available with the complement of the movement verb in (64), and finally (iv) the interpretation 'They saw Peio (while) Miren was working alone, too' is also unavailable with the TZEN complement in (65):

(62) Miren, [ $\Delta_{\mathrm{i}}$ bakarrik ego-te-a-n], beldurtzen da. Eta Peio ere. Miren.ABS alone stay-TZE-D-INE scare AUX and Peio.ABS too 'When staying alone, Miren gets scared. And Peio, too.'

strict $\mathbf{x}$

(63) Mireni $\left[\Delta_{\mathrm{i}}\right.$ bakarrik ego-teko $]$ esan diote.Eta Peiori ere. Miren.DAT alone stay-TZEKO say AUX and Peio.DAT too 'They told Miren to stay alone. And to Peio, too.'

strict $\mathbf{x}$

(64) Miren $\left[\Delta_{\mathrm{i}}\right.$ bakarrik ego-tera $]$ behartu dute. Eta Peio ere. Miren.ABS alone stay-TZERA force AUX and Peio.ABS too 'They forced Miren to stay alone. And Peio, too.' strict $\mathbf{x}$

(65) Miren $\left[\Delta_{i}\right.$ bakarrik lan egi-ten $]$ ikusi dute. Eta Peio ere. Miren.ABS alone work do-TZEN saw AUX and Peio.ABS too 'They saw Miren working alone. And Peio, too.'

strict $\mathbf{X}$

In sum, the strict reading is only available in the cases of ellipsis of finite clauses and argumental 
infinitives.

\subsection{4. 'Only $D P^{\prime}$ antecedents and the invariant reading}

The variability in the interpretations available when the antecedent of the silent subject is associated with the focus particle only constitutes another diagnostic for defining the type of non-overt subject in a clause. Consider the following two English examples:

(66) Only Churchill remembers [ $\Delta$ giving the BST speech].

invariant reading

$x$

(67) Only Churchill remembers that [ $\Delta$ giving the BST speech was momentous].

reading $\sqrt{2}$

invariant

The OC PRO in (66) has a unique interpretation, the bound variable interpretation, given in (68a). In other words, the only possible reading is the one in which the referent of the subject co-varies with its quantified antecedent. The invariant reading in (68b), where the subject freely refers to the discourse antecedent Chuchill, is not available.

(68) a. Churchill is the only $x$ such that $x$ remembers $x$ giving the BST speech.

b. Churchill is the only $\mathrm{x}$ such that $\mathrm{x}$ remembers Churchill giving the BST speech.

However, this type of interpretive restriction disappears with NOC PRO: (67) allows both the bound variable reading in (69a) and the invariant reading in (69b):

(69) a. Churchill is the only $x$ such that $x$ remembers that $x$ giving the BST speech was momentous.

b. Churchill is the only $\mathrm{x}$ such that $\mathrm{x}$ remembers that Churchill giving the BST speech was momentous.

Turning now to the data from Basque infinitives, we once again get the same distribution. On the one hand, the invariant reading is available for the silent subject in both finite clauses (70) and argumental infinitives (71) (the bound variable reading is available in both):

(70) Bakarrik Mirenek daki [ $\Delta$ lana galduko] duela. only Miren.ERG know work lose AUX.that 'Only Miren thinks that she will lose the job.'

Invariant reading: Miren is the only $x$ that thinks that Miren will lose the job

(71) Bakarrik Mirenek daki nahi luketela [ $\Delta$ lana uztea].

only Miren.ERG know want AUX.that work leave.TZE.D.ABS

'Only Miren knows that they would like her to leave the job.'

Invariant reading: Miren is the only x that knows that they would like Miren to leave the job $\checkmark$

Conversely, the invariant reading is not available for the subject of infinitival adjuncts (72), the subject of the complement of directive verbs (73), the subject of complements of motion verbs (74) or the subject of TZEN complements (75) (note that as in English, the bound variable reading is still available in all these cases):

(72) Bakarrik Miren beldurtzen da [ $\Delta$ lan egi-te-a-n].

only Miren.ABS scare AUX work do-TZE-D-INE 
'Only Miren gets scared when working.'

(Unavailable) invariant reading: Miren is the only $x$ that gets scared when Miren works $\mathbf{x}$

(73) Bakarrik Mireni esan diote [ $\Delta$ lan egi-teko].

only Miren.DAT say aux work do-TZEKO

'They only told Miren to work.'

(Unavailable) invariant reading: Miren is the only $x$ to whom they ordered that Miren must work $\mathbf{x}$

(74) Bakarrik Miren behartu dute [ $\Delta$ lan egi-tera].

only Miren.ABS force AUX work do-TZERA

'They only forced Miren to work.'

(Unavailable) invariant reading: Miren is the only $x$ that they forced so that Miren works $\mathbf{x}$

(75) Bakarrik Miren ikusi dute [ $\Delta$ lan egi-ten].

only Miren.ABS see AUX work do-TZEN

'They only saw Miren working.'

(Unavailable) invariant reading: Miren is the only $x$ that they saw (while) Miren was working $\mathrm{x}$

In the next (and) last subsection, we will see that we obtain the same result with the test of the de se vs. de re interpretations.

\subsubsection{The de re reading}

A final property that distinguishes NOC constructions from OC constructions is that it allows a non de se reading in intensional contexts. To illustrate this contrast, let us take a context in which a war hero suffering from amnesia watches a TV program describing his deeds, and that he does not realize that the program is about him. The situation will be accurately described by (76a) but not by (76b). That is, only the NOC constructions allow a non de se reading.

(76) a. The unfortunate believes that [getting a medal] would be boring.

b. The unfortunate expects [to get a medal].

In Basque, the data I have compiled with respect to the de se/de re contrast show that the de re reading -i.e. the reading in which the unfortunate does not know that he is the one he sees on tvis allowed in the same context in finite clauses (77), as well as in argumental infinitives (78):

(77) Gizarajoak ${ }_{\mathrm{i}}\left[\Delta_{\mathrm{i} j}\right.$ domina jasoko du-ela $] \quad$ espero du. unfortunate.ERG medal get.FUT AUX.3sgABS.3sgERG-that expect AUX 'The unfortunate expects that he will get a medal.'

(78) Gizarajoak $\mathrm{i}_{\mathrm{i}}\left[\Delta_{\mathrm{i} / \mathrm{j}}\right.$ domina jaso-tze-a $]$ espero du. unfortunate.ERG medal get-TZE-D-ABs expect AUX 'The unfortunate expects to get a medal.'

On the contrary, this reading is not available with complements of directive verbs (79) or infinitival adjuncts (80). It is not available with TZERA and TZEN complements either (81)-(82):

(79) Gizarajoari $\mathrm{i}_{\mathrm{i}} \quad\left[\Delta_{\mathrm{i} / *_{\mathrm{j}}}\right.$ domina jaso-tzeko] agindu diote. unfortunate.DAT medal get-TZEKO order AUX 'They ordered the unfortunate to get a medal.' 

(80) Gizarajoa $_{\mathrm{i}}$
poztu da $\left[\Delta_{\mathrm{i} /{ }^{*} \mathrm{j}}\right.$
domina jaso-tze-a-n].
unfortunate.ABS glad AUX medal get-TZE-D-INE
'The unfortunate got happy when he received a medal.'
(81) Gizarajoa [ $_{\mathrm{i}} \mathrm{\Delta}_{\mathrm{i} / \mathrm{j}}$ domina jaso-tzera $]$ joan da.
unfortunate.DAT medal get-TZERA go AUX
'The unfortunate went to get the medal.'
(82) Gizarajoa ${ }_{\mathrm{i}} \quad\left[\Delta_{\mathrm{i} /{ }^{*} \mathrm{j}}\right.$ domina jaso-tzen $]$ ikusi dut. unfortunate.DAT medal get-TZERA see AUX
'I saw the unfortunate getting the medal.'

That is, only finite clauses and argumental infinitives have the properties of NOC with respect to the de se/de re contrast.

The battery of tests that I have appealed to here is usually used as a diagnostic to distinguish Obligatory Control from Non Obligatory Control constructions. ${ }^{\text {xxviii }}$ In this case, I have applied these tests to the different types of nominalizations of Basque that I am studying in this paper, and they have consistently showed the following classification:

(83) NOC PRO: finite clauses, argumental infinitives

OC PRO: complements of directive verbs, complements of motion verbs, TZEN complements

Recall that we are trying to analyze which condition or property makes pro-drop possible in argumental infinitives and disallows it in complements of directive verbs and infinitival adjuncts, while all three are constructions in which overt subjects are licensed. From that point of view, it is interesting to note that argumental infinitives pattern with finite clauses and that the complements of directive verbs and the infinitival adjuncts pattern with the infinitive complements that cannot license an overt subject. Hence, whatever the syntactic property of the subject of finite clauses is that makes it different from the (null) subject of TZEN or TZERA complements, it is also what makes the subject of argumental infinitives different from that of complements of directive verbs or infinitive adjuncts.

Now, we know well that the main difference between finite clauses and OC clauses is that the subject gets assigned structural Case in the first one but not in the second one. Hence, given the asymmetry exhibited by argumental infinitives on the one hand, and infinitival adjuncts and complements of directive verbs on the other hand, it is natural to conclude that subjects are assigned structural Case in argumental infinitives but not within the complements of directive verbs or within infinitival adjuncts. If this is so, we have further data in favor of a distinction between the two infinitives in terms of structural Case. That is, the data suggests that the subject is assigned structural Case within argumental infinitives but not within infinitival adjuncts and complements of directive verbs.

\subsection{Quantifier float}

In this section, we will see that data from quantifier float provides further evidence in favor of the claim made above that only subjects in argumental infinitives are assigned Case.

Unlike quantifiers like all or both in English, most of Basque quantifiers cannot float ( $c f$. Artiagoitia 2003b). However, Artiagoitia (2003b) identifies oro 'all/every' as a floating quantifier (cf. also Lafitte 1944). ${ }^{\text {xxix }}$ Let us briefly analyze the syntactic properties of oro. In Basque, the case-marker attaches to the rightmost element in the DP, be it a noun (90), an adjective (91) or a quantifier (92), depending on the (fixed) word order inside the nominal: ${ }^{\text {xxx }}$ 
(90) [Lau liburuak]-ø

four book.D.pl-ABS

'The four books'

(91) [Liburu handie]-k

book big.D.pl-ERG

'The big books'

(92) [Liburu guztie]-k

book all.D.pl-ERG

'All the books'

The quantifier oro, like the quantifier guzti 'all' illustrated in (92), can appear to the left of the case-marker and to the right of the noun, inside the DP. This is illustrated in (93):

(93) a. [Gizon oro]-k lan egin du. man all-ERG work do AUX.3sgABS.3pleRG

'All men worked.'

b. [Gizon oro]-ø etorri da. man all-ABS come AUX.3plaBs

'All men came.'

But unlike guzti, oro can also show a different pattern in certain dialects. Indeed, beside (93), some speakers of North-Eastern Basque accept the pattern illustrated in (94) (cf. Artiagoitia 2003b). Notice that what distinguishes this second pattern from the general one examined above is that here the case-marker appears on both the nominal and oro, as in the cases of floating quantifiers in many other languages ( $c f$. Bobaljik 2003): ${ }^{x x x i}$

(94) a. Gizonek oro-k lan egin dute.

man.D.pl.ERG all-ERG work do AUX.3sgABS.3pleRG

'All men worked.'

b. Gizonak- $\varnothing$ oro-ø etorri dira.

man.D.pl-ABS all-ABS come AUX.3plABS

'All men came.'

c. Gizon eta emazteak- $\varnothing$ oro-ø hor ziren, laneko prest. man and woman.pl-ABS all-ABS there AUX.3plABS work.for ready 'All men and women were there, ready for work.'

And crucially, these case-marked elements can appear separated in the clause:

(95) a. Gizonek lan egin dute oro-k. man.D.pl.ERG work do AUX.3sgABS.3pleRG all-ERG

'All men worked.'

b. Gizonak etorri dira oro.

man.D.pl.ABS come AUX.3plaBs all.ABS

'All men came.'

c. Gizon eta emazteak hor ziren oro, laneko prest. man and woman.pl.ABS there AUX.3plABS all work.for ready

'All men and women were there, ready for work.'

Following Artiagoitia (2003b), I will assume that the clauses in (95) show instances of floating quantifiers. Now, I will also assume that floating quantifiers are associated with (intermediary) 
traces of DPs (Sportiche 1988, Déprez 1989, Bošković 2004), left by A-movement (and not A'-movement, $c f$. Déprez 1989). In other terms, adopting also the hypothesis that A-movement is related to Case-Agreement phenomena, I will assume that floating quantifiers are only licensed if the DP they are associated with is assigned structural Case. ${ }^{\text {xxxii }}$ Recall that I am claiming that it is only the subjects in argumental infinitives that are assigned structural Case. This means that we predict that floating quantifiers associated with subjects will be licensed in argumental infinitives but not in infinitival adjuncts and in TZEKO complements of directive verbs.

As I illustrate below, this is borne out. First, the pair (96)-(97) shows that in argumental infinitives, oro is licensed either adjacent to the subject or separated from it, to the right of the non-inflected verb:

(96) Garrantzitsua da [gizon eta emazteak oro hor izai-te-a] laneko prest. important is man and woman.pl.ABSall there be-TZE-D.ABS work.for ready 'It is important for all of men and women to be there, ready for work.' (Lit. 'All of men and women being there, ready for work, is important.')

(97) Garrantzitsua da [gizon eta emazteak hor izai-te-a oro] laneko prest. important is man and woman.pl.ABS there be-TZE.D-ABS all work.forready 'It is important for all of men and women to be there, ready for work.'

That is, in argumental infinitives, the behavior displayed by oro is the same as the one displayed within main finite clauses (see (96)-(97) above). But the judgments are different when it comes to the behavior of oro within infinitival adjuncts (98)-(99) or within TZEKO complements of directive verbs (100)-(101):

(98) (?)[Gizon eta emazteak oro hel-tze-a-n], lanean hasiko gira. man and woman.pl.ABS all arrive-TZE-D-INE work.INE begin.FUT AUX 'When all of men and women will arrive, we will begin working.'

(99) *[Gizon eta emazteak hel-tze-a-n oro], lanean hasiko gira. man and woman.pl.ABS arrive-TZE-D-INE all work.INE begin.FUT AUX 'When all of men and women will arrive, we will begin working.'

(100) [Sarri gizoneta emazteak oro hor izai-teko] galdegin dut. tonightman and woman.pl.ABS all there be-TZEKO ask AUX 'I asked for all of men and women to be there tonight.'

(101)*[Sarri gizon eta emazteak hor izai-teko oro] galdegin dut. tonight man and woman.pl.ABS there be-TZEKO all ask AUX 'I asked for all of men and women to be there tonight.'

Whereas oro can appear adjacent to the subject in these constructions (see (98) and (100)), it cannot appear to the right of the verb ((99) and (101)). That is, quantifier float is not licensed with subjects of infinitival adjuncts or complements of directive verbs. In consequence, as predicted by the licensing condition on pro-drop that I proposed in (32), the overt subjects in argumental infinitives and other types of infinitives in Basque have a different syntax, and furthermore, this difference is to be accounted for in terms of structural Case.

\subsection{Extraction facts}

It is well-known that there is an asymmetry in the possibility of extracting arguments and adjuncts from certain types of contexts, which are customarily called 'weak islands' (cf. Huang 1982, Lasnik \& Saito 1984, Cinque 1990). For instance, as illustrated in (84)-(85), in English, extraction from an embedded wh-infinitive is (marginally) possible for a DP argument such as 
'which man', but not for an adjunct like 'how'.

(84) ?Which man are you wondering [whether to invite _]?

(85) *How are you wondering [whether to behave _]?

The same type of effect arises in Basque. As illustrated below, extraction of an argument from a wh-island is only slightly deviant (be it a subject (86a) or an object (86b)), while extraction of an adjunct gives an ungrammatical result (87):

(86) a. ?Nork ez dakizu [noiz _ lagunduko gaitu-en]? who.ERG NEG know.2sg when help AUX.1plABs.3sgERG-C

Lit. 'Who don't you know when will help us?'

b. ?Nor ez dakizu [noiz _ lagunduko dugu-n]? who.ABS NEG know.2sg when help AUX.3sgABS.1pleRG-C

'Who don't you know when we will help?'

(87) *Noiz ez dakizu [nor _ lagunduko dugu-n]?

when NEG know.2sg who help AUX.3sgABS.1plerG-C

*'When don't you know who we will help?'

Now, interestingly for us, the same asymmetry can be observed with extraction from the TZEKO complement of directive verbs. ${ }^{\text {xxiii }}$ In the following examples, we can see that the object embedded in the TZEKO infinitive can be extracted (88a), while an adjunct like noiz 'when' cannot (88b): :xxiv

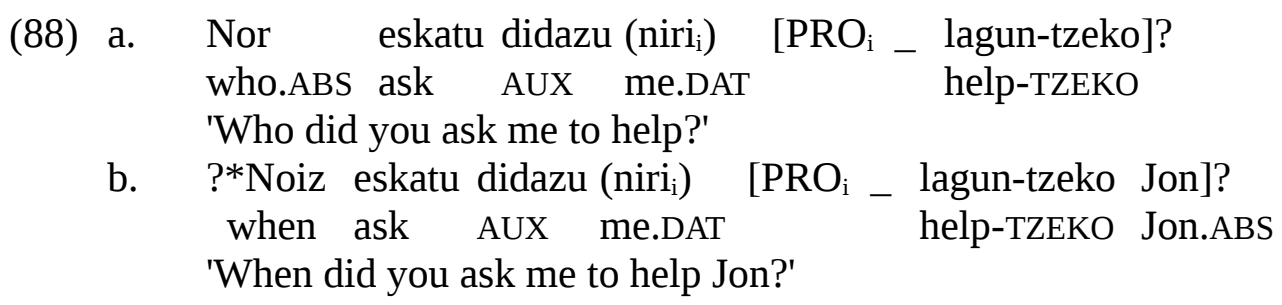

Based on this data, we can conclude that the TZEKO infinitives induce a weak island. Now, if we focus on the subject of the TZEKO infinitive, we can see that, as illustrated in (89b), its extraction also induces a weak island effect:

(89) a. (Zuk) (niri) [Mirenek Jon lagun-tzeko] eskatu didazu. you.ERG me.DAT Miren.ERG Jon.ABS help-TZEKO ask AUX Lit. 'You asked me Miren to help Jon.'

b. *Nork eskatu didazu [ _ lagun-tzeko Jon]? who.ERG ask AUX help-TZEKO Jon.ABS Lit. 'Who did you ask me to help Jon?'

My aim here is not to discuss the nature of weak islands, which seem to be quite a heterogeneous phenomenon ( $c f$. Szabolcsi 2006 and references given therein). Rather, I would like to focus on the data given above and study it as a minimal pair. We have two contexts where objects can extract and adjuncts cannot, and that we can thus consider as inducing a weak island effect. However, these contexts differ in that extraction of subjects is allowed in one of them only. In the extensive survey of the literature on weak islands made in Szabolcsi (2006), she concludes that semantic factors play an important part in the issue of what type of element is sensitive to weak islands (like the (in)definiteness, referentiality, etc. of the extracted element). However, she also 
admits that everything cannot be reduced to semantics, and that part of the phenomenon is syntactic in nature. When we observe the pair (86a)-(89b), it is clear that the contrast in the extraction of the subject nork cannot be accounted for in terms of its semantics, given that in both examples we have the same wh-phrase, with the same semantic properties. We must thus find an explanation in terms of the syntax of this subject. Again, they have a very similar syntax. On the one hand, they have the same theta-role, given that they both are agents. Then, they are both wh-phrases. Note also that an escape hatch must be available for both of them, given that the contexts in which they appear allow the extraction of the object. Thus the decisive factor must be related to the inflectional domain. In (86a), the subject clearly participates in Case-Agree relations. If the subject in the infinitive in (89b) also participated in Case-Agree relations, there would be no difference between them, and thus no explanation for the asymmetry in the induction of weak island effects. In consequence, an explanation in terms of Case seems to be the only option here: the subject of TZEKO complements is not assigned Case and thus cannot extract. Note that this explanation looks logical, in a sense: a DP without structural Case is less 'argumental' and more 'adjunct-like' than a DP with structural Case. In consequence, given that typically arguments can extract from weak islands and adjuncts cannot, it is not surprising that these in-between DPs show a behavior similar to that of adjuncts. ${ }^{\text {xxxv,xxxvi }}$

In sum, the contrasts we find between finite clauses and the TZEKO complements of directive verbs suggest that in the latter type of clauses, the subject is not assigned structural Case.

\subsection{Intermediary conclusions}

In this section, I have argued that subject-drop in Basque is ruled by the licensing condition on pro-drop repeated in (102):

(102) Licensing Condition on Pro-Drop:

A DP can be elided iff its Case feature is valued structurally.

In particular, I have argued that the only type of infinitive that allows subject-drop is also the only one in which the subject is assigned structural Case.

(i) First, we have seen that (102) on the one hand and the theory of control/raising on the other hand complete each other, in the sense that the first tells us what type of non-overt argument we expect to find when Case is assigned and the second tells us what type of non-overt argument we will find when Case is not assigned. In turn, this complementarity predicts that the two types of non-overt arguments will be in complementary distribution, and we saw that this is precisely the case.

(ii) Then, I have shown that the interpretive properties of argumental infinitives with regards to the non-overt subject are the same as that of finite clauses, in which subjects are assigned structural Case; in contrast, the interpretive properties of TZEKO complements and infinitive adjuncts converge with those of infinitives that do not license overt subjects (i.e., complements of directive verbs and complements of motion verbs).

(iii) Third, on the basis of the behavior of the floating quantifier oro 'all', I have presented additional evidence for the hypothesis that the only type of infinitive in which subjects are assigned case is argumental infinitive type. In infinitives, floating quantifiers can occur with subjects of argumental infinitives, but not with subjects of TZEKO infinitives or infinitive adjuncts. Assuming that floating quantifiers are the remnants of A-movement, and that A-movement is to be related to Case-assignment, we have concluded that this contrast indicates that the subjects of argumental infinitives are assigned structural Case, while the subjects of other types of infinitives are not. 
(iv) Finally, we have seen that TZEKO complements behave as weak islands and that within these infinitives, subjects pattern together with adjuncts in that they cannot be extracted. I have argued that this can only be accounted for if we assume that what makes the subject akin to an adjunct here is the fact that it is not assigned structural Case.

Summarizing, I have argued in favor of (102) on the basis of the behavior exhibited by the subjects in the whole range of infinitival constructions of Basque analyzed in this paper. This approach to the issue of pro-drop has also allowed us to study the morphosyntax of nominalizations in Basque. In particular, I have claimed that in the argumental infinitive construction, $\mathrm{T}$ assigns structural Case to its subject (and hence licenses subject-drop), while in the others types of nominalizations it does not. Nominalizations can thus have very different syntactic structures. This converges with previous works on infinitives in Basque, where it is argued that the internal syntax of infinitives in Basque is subject to variation (cf. Goenaga 1984, Ortiz de Urbina 1989, San Martin \& Uriagereka 2002, San Martin 2004, this volume, Etxepare 2005, Etxepare \& Uribe-Etxebarria 2009

). Also, I hope that apart from providing evidence in favor of an original take on pro-drop (the licensing condition in (102)), I have also convinced the reader that the study of infinitive clauses can be an interesting and fruitful way to handle the question of null arguments.

This result is also interesting in that it shows that, in a sense, argumental infinitives are not 'canonical' infinitives, given that, when their subject is non-overt, it does not have the interpretation of a controlled PRO. We could even call them 'pseudo-infinitives', in echo with the 'pseudo-finite' clauses of Brazilian Portuguese (cf. Ferreira 2000, Nunes 2008) or Japanese (Fujii 2006), where embedded clauses that at first sight seem to be finite appear to involve OC. ${ }^{\text {xxxvii }}$

Finally, our conclusions have further consequences for the theory of Case. Indeed, as we already discussed in section 4.1, if we say that structural Case is not available for subjects inside complements of directive verbs (103a) or infinitival adjuncts (103b), we must conclude that the overt subject that is licensed in these constructions is not assigned structural Case:

(103) a. [Jonek ardoa erosteko] agindu didate.

Jon.ERG wine.ABS buy-TEKO order AUX.3sgABS.1sgDAT.3pleRG

Lit. 'They ordered me Jon to buy wine.'

b. [Negua etor-tze-a-rekin], enarak badoaz. winter.ABS come-TZE-D-with swallows.ABS go.3plABS

'With the coming of the winter, the swallows leave.'

In the following section, I explore the issue of why it is that structural Case is assigned to subjects in argumental infinitives but not in other types of nominalizations. I do not develop any specific proposal, but I discuss data that show that it is not the case that all argumental infinitives have this Case-assigning property. That is, I will argue that structural Case assignment to subjects is an optional feature of argumental infinitives.

\section{Null subjects and controlled non-overt subjects in argumental infinitives}

I began this paper by classifying nominalized clauses with respect to the syntactic role they play in the main clause and with respect to their morphology (i.e. the suffixes that attach to the -tze morpheme), following Artiagoitia (2003a). The analysis I have developed of the behavior of the subject within these infinitives in the preceding sections allows us to further classify them into the following groups (104):

(104) Table 2. Classification of TZE nominalizations 


\begin{tabular}{|c|c|c|c|c|c|}
\hline & \multicolumn{3}{|c|}{ A } & \multirow{2}{*}{\multicolumn{2}{|c|}{ B }} \\
\hline & $\mathrm{A} 1$ & \multicolumn{2}{|c|}{ A2 } & & \\
\hline & $\begin{array}{l}\text { Argumental } \\
\text { infinitives }\end{array}$ & Infinitival adjuncts & $\begin{array}{l}\text { Complements of } \\
\text { directive verbs }\end{array}$ & $\begin{array}{l}\text { Complements of } \\
\text { verbs of motion }\end{array}$ & $\begin{array}{c}\text { TZEN } \\
\text { complements }\end{array}$ \\
\hline Overt subject & $\checkmark$ & $\checkmark$ & $\checkmark$ & $x$ & $x$ \\
\hline Null subject & $\checkmark$ & $x$ & $x$ & $x$ & $x$ \\
\hline Structural Case & $\checkmark$ & $x$ & $x$ & $x$ & $x$ \\
\hline
\end{tabular}

As shown in (104), we end up with a three-way system. First, argumental infinitives are of type A1: they assign Case to their subject. Secondly there is the group of infinitives of type A2, with infinitival adjuncts and TZEKO complements of directive verbs, where overt subjects are licensed but are not assigned structural Case, and where null subjects are not licensed. Third, in type B infinitives, i.e., TZERA and TZEN complements, overt subjects are never licensed and the non-overt subjects are always controlled.

The table 2 in (104) suggests that there is a very strict correlation between the syntactic and semantic role of the infinitive with respect to the main clause and its internal structure. For instance, it seems that when an infinitive is an argument of the main verb, it acquires the ability to assign structural Case to (and to pro-drop) its internal subject. ${ }^{\text {xxviii }}$ This hypothesis is also suggested in San Martin \& Uriagereka (2002): "plausibly pro is only licensed in domains which have been Case-assigned" (cf. also Ortiz de Urbina (1989) and San Martin (2004) for the hypothesis that overt subjects are licensed in infinitives that are themselves case-marked). ${ }^{\text {xxxix }}$ However, as we will see below, some facts show that the data is more complex than what is suggested by the table in (104). More precisely, we will see that some argumental infinitives appear to correspond to type B in (104). We will thus be lead to the conclusion that the Case-assignment property -and thus the ability to drop subjects- is actually optional in argumental infinitives. First, I will gather data that can be found in different works on Basque nominalizations that show that overt subjects are not always licensed in argumental infinitives (section 5.1). Then, I will present a detailed analysis of infinitives in which the direct object surfaces with a genitive-marker, and which are control constructions (section 5.2).

\subsection{Argumental infinitives without an overt subject}

Goenaga (1984) and San Martin (this volume) show that not all infinitives in object position have the properties of NOC (I refer the reader in particular to San Martin's paper in this volume for all the relevant tests; $c f$. also Ortiz de Urbina (1989)). In the following examples for instance, the silent subject of the infinitival clause has a controlled interpretation (examples from Goenaga 1984: 281):
(105) $\left[\Delta_{\mathrm{i}}\right.$ txinera ikas-te-a-ri $]$ ekin zion Jonek $\mathrm{k}_{\mathrm{i}}$
Chinese.ABS learn-TZE-D-DAT get.down AUX.3sgDAT.3sgERG Jon.ERG 'Jon got down to learning Chinese.'
(106) Niri $_{i}$ ahaztu egin zitzaidan $\quad\left[\Delta_{\mathrm{i}}\right.$ leihoa ix-te-a]. me.DAT forget do AUX.3sgABS.1sgDAT window.ABS close-TZE-D.ABS 'I forgot to close the window.'
(107) Niri $_{\mathrm{i}}$ asko kosta zitzaidan $\quad\left[\Delta_{\mathrm{i}}\right.$ txinoera ikas-te-a]. me.DAT much cost AUX.3sgABS.1sgDAT Chinese.ABS learn-TZE-D.ABS 'I took me a great deal of effort to learn Chinese.'

It seems actually -as also noted in Goenaga (1984) and San Martin (2004)- that the OC vs. NOC 
properties of absolutive or dative infinitives will depend on the predicate that they are selected by. ${ }^{\mathrm{xl}}$ As a first approximation, building on the examples one can find in the literature, I can say that verbs like ekin 'get down to', ahaztu 'forget', kostatu 'be difficult, cost', erabaki 'decide', pentsatu 'think', and lortu 'to achieve, to get' select OC infinitival clauses while espero 'hope', nahi 'want', and behar 'need' select NOC infinitival clauses. A more detailed analysis of the predicates selecting infinitival arguments would be necessary in order to have a clearer idea of the nature of the distribution between those that select clauses with NOC properties and those that select clauses with OC properties. For the time being, we will simply conclude that, once we focus on specific selecting verbs, we can see that argumental infinitives that have the syntax of TZERA complements of motion verbs or TZEN complements (i.e. type B infinitives in (104)) can be found in all dialects of Basque.

Another case in which we can observe an alternation between different types of argumental infinitives is the one we find in cases of Long Distance Agreement (LDA), analyzed in Etxepare $(2003,2005)$. LDA is the name given to the cases in which a main verb agrees in number with an object embedded in an argumental infinitive (absolutive or dative):

(108) a. [Nobela erromantikoak irakur-tze-a] gustatzen zaio. novel romantic.pl.ABS read-TZE-D.ABS like AUX.3sgABS.3sgDAT 'He/she likes to read romantic novels.'

b. [Nobela erromantikoak irakur-tze-a] gustatzen zaizkio. novel romantic.pl.ABS read-TZE-D.ABS like AUX.3plABS.3sgDAT 'He/she likes to read romantic novels.'

In his study of these constructions in Basque, Etxepare (2003, 2005) shows that for LDA to be possible, the subject must be silent and controlled by a higher DP (that is, there can be no intervening DP). As illustrated below, even in argumental infinitives in which overt subjects are licensed (109a), LDA is blocked if the subject is overt (109b):

(109) a. Jonek $\mathrm{i}_{\mathrm{i}}\left[\Delta_{\mathrm{i} / *_{\mathrm{j}}} / \mathrm{zuk}_{\mathrm{j}}\right.$ traste zaharrak bota-tze-a] erabaki du. Jon.ERG you.ERG thing old.pl.ABSthrow-TZE-D decide AUX.3sgABS.3sgERG 'Jon decided to throw off the old things.'

b. Jonek ${ }_{\mathrm{i}}\left[\Delta_{\mathrm{i} / *_{\mathrm{j}}} /\right.$ zuk $_{\mathrm{j}}$ traste zaharrak bota-tze-a] erabaki ditu. Jon.ERG you.ERG thing old.pl.ABS throw-TZE-D decide AUX.3plABS.3sgERG 'Jon decided to throw off the old things.'

This asymmetry suggests once again that there are argumental infinitives with fundamentally different internal structure and, consequently, with fundamental differences with respect to the ability to license null arguments in subject position.

In the following section, I study the case of the genitive-marked objects in North-Eastern Basque, and show that the infinitives in which they appear also constitute cases in which (i) structural Case is not assigned to the subject and (ii) null subjects are not licensed.

\subsection{Genitive objects in North-Eastern Basque}

The North-Eastern varieties of Basque have a long-known property: in infinitival constructions, instead of bearing absolutive case, the object can surface with a genitive marker (known as the TO-GEN phenomenon; $c f$. Heath 1972, Goenaga 1984, Ortiz de Urbina 1989). ${ }^{x l i}$ This is illustrated in (109), where the genitive object appears inside an argumental infinitive:

(110) $\mathrm{Nik}_{\mathrm{i}}$ [ $\Delta_{\mathrm{i}}$ ator honen janz-te-a] gustoko dut. 
I.ERG shirt this.GEN wear-TZE-D.ABS like AUX.3sgABS.1sgERG

'I like wearing this shirt.'

This genitive has some interesting properties. First, in addition to the contexts like the absolutive argumental infinitive illustrated in (110), it can appear in any type of nominalization: in ergative and dative argumental infinitives (111)-(112), in complements of directive verbs (113), in infinitival adjuncts (114), in complements of verbs of motion (115), and in TZEN complements (116). ${ }^{\text {xli }}$

(111) $\left[\Delta_{\mathrm{i}}\right.$ ator honen janz-te-a-k] niri $\mathrm{i}_{\mathrm{i}}$ plazerra ematendit. shirt this.GEN wear-TZE-D-ERG me.DAT pleasure.ABS give AUX.3sgABS.1sgDA T.3sgERG

'Wearing this shirt is very pleasant for me. (Lit. Wearing this shirt gives me a lot of pleasure.)'

(112) $\mathrm{Nik}_{\mathrm{i}} \quad\left[\Delta_{\mathrm{i}}\right.$ ator honen janz-te-a-ri] garrantzia ematen diot.

I.ERG shirt this.GEN wear-TZE-D-DAT importance.ABS give AUX.3sgABs.3sg

DAT.1sgERG

'I give importance to wearing this shirt.'

(113) $\mathrm{Ni}_{\mathrm{i}}-\mathrm{ri} \quad\left[\Delta_{\mathrm{i}}\right.$ ator honen janz-teko $]$ erran didate.

me-DAT shirt this.GEN wear-TZEKO say AUX.3sgABS.1sgDAT.3pleRG

'They told me to wear this shirt.'

(114) $\left[\Delta_{\mathrm{i}}\right.$ ator honen janz-te-ko], $\mathrm{ni}_{\mathrm{i}}$ argaldu beharko naiz.

shirt this.GEN wear-TZE-for me.ABS lose.weightmust AUX.3sgABS 'I will have to lose weight in order to wear this shirt.'

(115) $\mathrm{Ni}_{\mathrm{i}} \quad\left[\Delta_{\mathrm{i}}\right.$ ator honen janz-tera $]$ igorri naute.

me.ABS shirt this.GEN wear-TZERA send AUX.1sgABS.3plERG

'They sent me to wear this shirt.'

(116) $\mathrm{Ni}_{\mathrm{i}} \quad\left[\Delta_{\mathrm{i}}\right.$ ator honen janz-ten] ikusi naute.

me.ABS shirt this.GEN wear-TZEN see AUX.1sgABS.3plERG

'They saw me wearing this shirt.'

Second, the non-overt subject in these clauses is not a null subject as we defined it here: as indicated by the indexing in the examples in (111)-(116), the interpretation of the non-overt subjects is dependent on that of a higher DP. That is, these subjects are controlled non-overt DPs (i.e. they are either PROs or NP-traces).

Third, genitive objects are not allowed when the subject of the nominalized clause is overt. That is, even in the types of nominalization in which overt subjects are licensed (cf. section 1 ), overt subjects are not licensed when the object is genitive (cf. also Goenaga (1984: 102)). This is illustrated in (117) with an absolutive infinitive, in (118) with a TZEKO complement, and in (119) with an infinitival adjunct:

(117) *[Jonek Miren-en lagun-tze-a] zaila da. Jon.ERG Miren-GEN help-TZE-D.ABS difficult AUX.3sgaBS

'It is difficult for Jon to help Miren. (Lit. Jon helping Miren is difficult)'

(118) *[Jonek Miren-en lagun-tzeko] erran didate.

Jon.ERG Miren-GEN help-TZEKO say AUX.3sgABS.1sgDAT.3pleRG

'They told me Jon to help Miren.'

(119) *[Jonek Miren-en lagun-tze-ko], biak bildu beharko dira. Jon.ERG Miren-GEN help-TZE-for two.D gather must AUX.3plaBS

'For Jon to help Miren, both will have to meet.' 
Finally, remember that we saw that the subject of argumental infinitives, contrary to the other type of infinitives, has the properties of NOC ( $c f$. section 4.4). Interestingly, with genitive objects, the pattern changes, and the diagnostic tests show that the silent subjects accompanying them have OC properties: it cannot have a long-distance or non-c-commanding antecedent (120)-(121), it cannot have a strict reading under ellipsis (122), or an invariant reading when bound by an only DP (123):

$(120) *[\mathrm{e}]_{\mathrm{i}}$ badakit [Jonek [ $\Delta_{\mathrm{i}}$ Miren-en lagun-tze-a $]$ gustuko du-ela]. know.1sgerg Jon.ERG Miren-GEN help-TZE-D.ABS like AUX-that 'I know that Jon likes (me) to help Miren.'

(121) $*$ Jonen $_{\mathrm{i}}$ anaiak $\left[\Delta_{\mathrm{i}}\right.$ Miren-en lagun-tze-a] gustuko du. Jon.GEN brother.ERG Miren-GEN help-TZE-D.ABS like AUX.3sgERG 'Jon ${ }_{\mathrm{i}}$ 's brother likes $\left(\mathrm{him}_{\mathrm{i}}\right)$ to help Miren.'

(122) $\left[\Delta_{\mathrm{i}}\right.$ Miren-en lagun-tze-a] gustuko dut. Eta zuk ere. Miren-GEN help-TZE-D.ABS like AUX.1sgERG and you.ERG too 'I like helping Miren. And you do, too.' Unavailable reading: 'You like it when I help Miren.'

(123) Bakarrik Peiok gustuko du [ $\Delta$ Miren-en lagun-tze-a]. only Peio.erg like AUX.3sgerg Miren-GEN help-TZE-D.ABS 'Only Peio likes helping Miren.' Unavailable reading: 'Peio is the only x that likes it when Peio helps Miren.'

That is, all the properties of nominalizations with genitive correspond to those exhibited by the TZERA complements of verbs of motion or the TZEN complements in section 4.2. These data show again that Table 2 in (104) is not quite accurate, in that (i) it is not the case that the subject is assigned structural Case in all the constructions that we called argumental infinitives ( $c f$. also section 5.1), and furthermore (ii) it is not the case that argumental infinitives, TZEKO complements of directive verbs and infinitival adjuncts always license an overt subject in the first place. That is, they can all correspond to what we called type B in Table 2.

In sum, the types of nominalizations that we studied in this paper are not uniform in terms of their internal structure. Argumental infinitives can correspond (at least) either to a clause with an overt subject and a case-assigning $\mathrm{T}$ head or to a clause which does not project a TP and cannot license overt subjects internal to the infinitival constituent. Similarly, overt subjects are not always licensed in complements of directive verbs and infinitival adjuncts.

In consequence, taking into account the structural variation found among nominalizations which look the same on the surface, we can further specify our table in (104) as in (124).

(124) Table 3. Classification of TZE nominalizations

\begin{tabular}{|c|c|c|c|}
\hline & \multicolumn{2}{|c|}{ A } & \multirow{2}{*}{ B } \\
\hline & A1 & A2 & \\
\hline Overt subject & $\checkmark$ & $\checkmark$ & $x$ \\
\hline Null subjects & $\checkmark$ & $x$ & $x$ \\
\hline \multirow[t]{2}{*}{ Structural Case } & $\checkmark$ & $x$ & $x$ \\
\hline & -Argumental infinitives & $\begin{array}{l}\text { - Infinitival adjuncts } \\
\text { - Complements of } \\
\text { directive verbs }\end{array}$ & $\begin{array}{l}\text { - Complements of verbs of motion } \\
\text { - TZEN complements } \\
\text { - Argumental infinitives } \\
\text { - Infinitival adjuncts } \\
\text { - Complements of directive verbs }\end{array}$ \\
\hline
\end{tabular}


That is, even if it is true that subjects can be assigned structural Case and/or dropped only in argumental infinitives, not all argumental infinitives have such properties. ${ }^{\text {xliii,xliv }}$ We can thus conclude the following.

(i) Argumental infinitives, which on the surface seem to constitute a uniform type of construction, can be syntactically of very different types. In particular, it is not the case that the subject is assigned structural Case in all of them.

(ii) Unlike the hypothesis that we first made ( $c f$. San Martin \& Uriagereka 2002), subject pro-drop in infinitives cannot be strictly related to the argumental nature of these constructions. More elements seem to play a role: the selecting predicate, whether the object in the infinitive is in a long distance agreement relationship with the main clause, and the case the object is assigned. It is thus ultimately by getting a better understanding of these grammatical phenomena that we will be able to better understand also why the subject is assigned structural Case in some argumental infinitives but not in others.

\section{Conclusions}

In this article, I have argued that pro-drop is ruled by the condition on the assignment of structural Case in (125):

\section{(125) Licensing Condition on Pro-Drop:}

A DP can be elided iff its Case feature is valued structurally.

I have provided evidence in favor of (125) from the analysis of Basque subject-drop in non-finite contexts.

The licensing condition in (125) is not limited to subject-drop in Basque nominalizations. Rather, as stated, it scopes over any type of argument (not only subjects), and also over any language (structural Case seems to be a universal phenomenon). The question whether (125) can account for the whole pro-drop phenomenon is still an open issue which I address in Duguine (2012). But the hypothesis I have defended in this paper also opens a new approach to the problem of pro-drop, where the question of the 'richness' of agreement, mentioned in the introduction, is not considered to be the basic issue for the explanation of pro-drop, and where in consequence, we can look for a unitary explanation for pro-drop in languages with and without agreement morphology (see Duguine (2012) for cross-linguistic evidence in favor of (125), and also for a discussion of the question of the role that agreement morphology plays with respect to pro-drop). Finally, the last section of the paper was devoted to the question of why Case is assigned to the subject in argumental infinitives but not in other types of nominalizations. I argued that this property is not to be related to the argumental nature of argumental infinitives, given that we can find constructions in which the subject is not assigned Case in argumental infinitives (more precisely, overt subjects are not even licensed in these contexts). We saw that the study of independent questions about the selection of nominalizations and the morphosyntax of objects inside uninflected clauses may bring important insight to this issue, a line of inquiry I leave for future work.

Adger, D. 2007. "Three domains of finiteness: A minimalist perspective". In Finiteness: Theoretical and Empirical Foundations, I. Nikolaeva (ed.), 23-58. Oxford: Oxford University Press.

Albizu, P. 1997. "Generalized Person-Case Constraint: A case for a syntax-driven inflectional morphology”. In Theoretical issues at the morphology-syntax interface, Supplements to 
ASJU XL, A. Mendikoetxea \& M. Uribe-Etxebarria (eds.), 1-33. Donostia: UPV/EHU. Arteatx, I.. This volume. "Perception verb complements in Basque".

Artiagoitia, X. 2003a. “Complementation”. In A Grammar of Basque, J.I. Hualde \& J. Ortiz de Urbina (eds.), 640-718. Berlin: Mouton de Gruyter.

Artiagoitia, X. 2003b. "Oharrak determinatzaileen inguruan: oro-k dioena”. In Euskal gramatikari eta literaturari buruzko ikerketak XXI. mendearen atarian, Iker 14, J.M. Makazaga \& B. Oyharçabal (eds.), 137-159. Bilbao: Euskaltzaindia.

Bobaljik, J. 2003. "Floating quantifiers: Handle with care”. In $2^{\text {nd }}$ GLOT International State of the Article Book, 107-148. Berlin: Mouton de Gruyter.

Boeckx, C., N. Hornstein \& J. Nunes. 2010. Control as movement. Cambridge: Cambridge University Press.

Bošković, Ž. 2004. "Be careful where you float your quantifiers”. Natural Language and Linguistic Theory 22: 681-742.

Bouchard, D. 1984. On the content of empty categories. Dordrecht: Foris.

Chomsky, N. 1982. Some concepts and consequences of the Theory of Government and Binding. Cambridge, Mass.: MIT Press.

Chomsky, N.. 1986. Knowledge of language. Its nature, origin, and use. New York: Praeger.

Chomsky, N. 2000. "Minimalist inquiries: the framework". In Step by step: Papers in honor of Howard Lasnik, R. Martin, D. Michaels \& J. Uriagereka (eds.). Cambridge, Mass.: MIT Press, 89-155.

Cinque, G. 1990. Types of A'-Dependencies. Cambridge, Mass.: MIT Press.

Duguine, M. 2008. "Silent arguments without pro: the case of Basque". In The limits of syntactic variation, 311-329. M.T. Biberauer (ed.), Amsterdam: J. Benjamins.

Duguine, M. 2012. Null arguments in variation. Doctoral Dissertation, UPV/EHU \& Université de Nantes.

Elordieta, A. 2002. "The role of verbal agreement in licensing null arguments”. In Kasu eta komunztaduraren gainean, B. Fernandez \& P. Albizu (eds.), 113-132, Donostia: $\mathrm{UPV} / \mathrm{EHU}$.

Etxeberria, U. 2005. Quantification and domain restriction in Basque. Doctoral Dissertation, UPV/EHU.

Etxepare, R. 2003. Urruneko komunztadura eta menpeko infinitiboak euskaraz.

Lapurdum 8: 167-206.

Etxepare, R. 2005. “Number long distance agreement in (substandard) Basque”. In Studies in Basque and historical linguistics in memory of R. L. Trask, J. Lakarra \& J.I. Hualde (eds.), Supplements to ASJU, 303-350. Donostia: UPV/EHU.

Etxepare, R. \& M. Uribe-Etxebarria. 2009. "Hitz hurrenkera eta birregituraketa euskaraz”. In Beñat Oihartzabali gorazarre- Festschrift for Bernard Oyharçabal, R. Etxepare, R. Gómez \& J. Lakarra (eds), Supplements to ASJU, 335-355. Donostia: UPV/EHU.

Ferreira, M. 2000. Argumentos nulos em Português Brasileiro. M.A. Thesis, Universidade Estadual de Campinas.

Fujii, T. 2006. Some theoretical issues in Japanese control. Doctoral dissertation, University of Maryland, College Park.

Goenaga, P. 1980. Gramatika bideetan. Donostia: Erein, 2nd edition.

Goenaga, P. 1984. Euskal sintaxia: konplementazioa eta nominalizazioa. Doctoral dissertation, UPV/EHU.

Haddican, B. 2009. “A note on Basque participles”. In Beñat Oihartzabali gorazarre- Festschrift for Bernard Oyharçabal, R. Etxepare, R. Gómez \& J. Lakarra (eds), Supplements to ASJU, 423-433. Donostia: UPV/EHU. 
Haegeman, L. 1985. "INFL, COMP and nominative case assignment in Flemish infinitivals". In Features and Projections, P. Muysken \& H. van Riemsdijk (eds.), 123-137. Dordrecht: Kluwer.

Heath, J. 1972. “Genitivization in Northern Basque complement Clauses”. International Journal of Basque Linguistics and Philology (ASJU) 6: 46-66.

Holmberg, A. 2005. "Is there a little pro? Evidence from Finnish". Linguistic Inquiry 36(4): 533-564.

Holmberg, A. \& I. Roberts. 2010. "Introduction: parameters in minimalist theory”. In Parametric variation, T. Biberauer, A. Holmberg, I. Roberts \& M. Sheehan (eds), 1-57. Cambridge: Cambridge University Press.

Hornstein, N. 1999. “On control”. Linguistic Inquiry 30: 69-96.

Huang, C.T.J. 1982. Logical relations in Chinese and the theory of grammar. Doctoral Dissertation, MIT.

Lafitte, P. 1944 [1962]. Grammaire Basque (Navarro-Labourdin Littéraire), Reviewed and corrected edition. Baiona: Editions des "Amis du Musée Basque" \& Ikas.

Laka, I. 2006. "Deriving split ergativity in the progressive”. In Ergativity, A. Johns et al. (eds.), 173-195. Amsterdam: Springer.

Landau, I. 2000. Elements of control: Structure and meaning in infinitive constructions. Dordrecht: Kluwer.

Landau, I. 2004. "The scale of finiteness and the calculus of control". Natural Language and Linguistic Theory 22: 811-877.

Lasnik, H. \& M. Saito. 1984. “On the nature of proper government”. Linguistic Inquiry 15: 235-289.

Legate, J. 2006. “Split absolutive”. In Ergativity, A. Johns (eds.), 143-171. Amsterdam: Springer.

Marantz, A. 2000. "Case and licensing". In Argument and case: explaining Burzio's generalization, E. Reuland (ed.), 11-30. Amsterdam: J. Benjamins.

McCloskey, J. 1985. "Case, movement and raising in Modern English”, in Proceedings of WCCFL 4, 190-205.

Mensching, G.. 2000. Infinitive Constructions With Specified Subjects. Oxford: Oxford University Press.

Nunes, J. 2008. "Inherent case as a licensing condition for A-movement: The case of hyper-raising constructions in Brazilian Portuguese”. Journal or Portuguese Linguistics 7: 83-108.

Ortiz de Urbina, J. 1983. "Empty categories and focus in Basque”. Studies in the Linguistic Sciences 15: 133-156.

Ortiz de Urbina, J. 1989. Parameters in the Grammar of Basque: A GB approach to Basque Syntax. Dordrecht: Foris.

Oyharçabal, B. 1991. “Théorie des pronoms nuls et diversité linguistique: Bilan”. In Memoriae Mitxelena Magistri Sacrum, Supplements to ASJU, J. Lakarra (eds.), 867-898. Donostia: UPV/EHU.

Oyharçabal, B. 1998. “Analyse des infinitives adnominales en Basque”. Lapurdum 2: 37-51.

Pesetsky, D. \& E. Torrego. 2004. “Tense, Case, and the nature of syntactic categories”. In The syntax of time, J. Guéron \& J. Lecarme (eds.), 495-539. Cambridge, Mass.: MIT Press.

Pires, A. 2007. “The Derivation of Clausal Gerunds”. Syntax 10: 165-203.

Rizzi, L. 1990. Relativized Minimality. Cambridge, Mass.: MIT Press.

San Martin, I. 2000. "Control in Basque". Proceedings of WCCFL 19, Somerville, MA: Cascadilla Press, 425-438.

San Martin, I. 2004. On subordination and the distribution of PRO. Doctoral Dissertation, University of Maryland.

San Martin, I. 2008. "Defective domains in Basque nominalized dependants". In Gramatika 
jaietan: Patxi Goenagari omenez, Supplements to ASJU LI, X. Artiagoitia \& J. Lakarra (eds.), 753-767. Donostia: UPV/EHU.

San Martin, I.. This volume. "Structural dependency and interpretation in Basque nominalized clauses".

San Martin, I. \& J. Uriagereka. 2002. “Infinitival complementation in Basque”. In Erramu boneta: A Festschrift for Rudolf P.G. De Rijk, Supplements to ASJU XLIV, X. Artiagoitia, P. Goenaga \& J. Lakarra (eds.), 597-609. Donostia: UPV/EHU.

Schütze, C. 1997. INFL in adult and child language. Doctoral Dissertation, MIT.

Sitaridou, I. 2002. The synchrony and diachrony of Romance infinitives with nominative subjects. Doctoral Dissertation, University of Manchester.

Sportiche, D. 1988. "A theory of floating quantifiers and its corollaries for constituent structure”. Linguistic Inquiry 19: 425-449.

Sundaresan, S., \& T. McFadden. 2009. "DP distribution and finiteness in Tamil and other languages: selection vs. Case”. Journal of South Asian Linguistics 2: 5-34.

Szabolcsi, A. \& F. Zwarts. 1993. "Weak islands and an algebraic semantics of scope taking”. Natural Language Semantics 1: 235-284.

Szabolcsi, A. 2006. “Strong vs. weak islands”. In The Blackwell Companion to Syntax, Volume $I V$, M. Everaert \& H. van Riemsdijk (eds.), 479-531. Oxford: Blackwell.

Trask, R.L. 2003. “The Noun Phrase: nouns, determiners and modifiers; pronouns and names”. In A Grammar of Basque, J.I. Hualde \& J. Ortiz de Urbina (eds.), 119-176. Berlin: Mouton de Gruyter.

Valmala, V. 2008. “Topic, focus, and quantifier float”. In Gramatika Jaietan. Patxi Goenagaren omenez, Supplements to ASJU LI,, X. Artiagoitia \& J. Lakarra (eds.), 837-857. Donostia: UPV/EHU.

Williams, E. 1980. "Predication”. Linguistic Inquiry 11: 203-238.

Wurmbrand, S. 2001. Infinitives: Restructuring and clause structure. Berlin: Mouton de Gruyter.

Zabala, I. \& J.C. Odriozola. 1996. “On the relation between DP and TP. The structure of Basque infinitivals”. Catalan Working Papers in Linguistics 5: 231-281. 
i I would like to thank Pablo Albizu, Hamida Demirdache, Ricardo Etxepare, Aritz Irurtzun, Nerea Madariaga, Jairo Nunes, Milan Rezac, Itziar San Martin, Myriam Uribe-Etxebarria, the anonymous reviewers and the audience at the $V^{\text {th }}$ Workshop of the European Net in Linguistics (EHU/UPV, Vitoria Gasteiz) where part of this material was presented. This study has been developed thanks to the projects FFI2008-04789/FILO and FFI2011-29218

from MICINN, the projects GIC07/144-IT-210-07 and HM-2009-1-1 from the Basque government, Towards a Syntactic Atlas of the Basque Language from ANR (ANR-07-CORP-033), as well as the UFI HiTeDi (UFI11/14, UPV/EHU)

These are the relevant abbreviations I will use in the text: $[e]=$ phonologically silent argument, AUX $=$ inflected auxiliary, $\mathrm{ABS}=$ absolutive, $\mathrm{DAT}=$ dative, $\mathrm{ERG}=$ ergative, $\mathrm{INE}=$ inessive, $\mathrm{D}=$ determiner SG = singular, PL = plural.

ii Furthermore, as shown by Albizu (1997), we cannot appeal to the presence of abstract agreement in infinitives, which would license pro-drop the same way agreement does in clauses with overt agreement morphology. Evidence against this analysis comes from the so-called Person Case Constraint (PCC), a syntactic constraint on agreement relations. In the languages in which the PCC holds, person agreement (1st or 2nd person) with the absolutive object is blocked by the dative object intervener ( $c f$. Ormazabal 2000). As illustrated in (i), Basque displays PCC effects in finite clauses. However, Albizu (1997) shows that this effect disappears in nominalized ditransitive clauses: here the direct object can be something other than 3rd person (cf. (ii)). This shows that the nominalized clause in (ii) does not involve any syntactic agreement.
(i) *Azpisapoek ni etsaiari saldu naiote.
traitors.ERG me.ABS enemy.DAT sell AUX.1sgABS.3plDAT.3pleRG

'The traitors sold me to the enemy.'
(ii) Gaizki iruditzen zait
[zuk ni etsaiari saltzea].
wrong seem AUX.3sgDAT.3sgABS you.ERG me.ABS enemy.DAT sell-TZE-D.ABS
'Your selling me to the enemy seems wrong to me.'

iii Other languages also license subject-drop in both finite and non-finite clauses. This is the case for instance of the Australian language Warlpiri (Legate 2006).

iv As we will see below, null subjects are only licensed in certain types of infinitives in Basque.

$\checkmark$ I assume that clauses without agreement morphology on $\mathrm{T}$, in languages with otherwise inflected agreement paradigms, are $\varphi$-featureless (cf. also Landau 2004).

vi I assume a DP-ellipsis analysis of null arguments (cf. Holmberg 2005, Duguine 2008, 2012).

vii See Duguine (2012) for a more precise formulation of the licensing condition on pro-drop. In particular, I reinterpret the assignment of structural Case as the valuation of a [D] feature on the inflectional head.

Also, it must be noted that, as it is formulated, (6) is a necessary but not sufficient condition for pro-drop. For instance, subjects that are assigned structural Case cannot be silent in poor agreement languages (cf. (1)). In Duguine (2012), this is also accounted for by the reinterpretation of Case-assignment as the valuation of the [D] feature on the inflectional head. That is, I argue that there is a single condition (which is a PF condition) that can account for both the licensing of pro-drop in rich agreement languages (like Basque) and languages with no agreement morphology (like Japanese) and the impossibility for subjects to drop in so-called poor agreement languages (languages like English or French).

viii Anyhow, in this section we will not focus on non-overt subjects. This is why only $\Delta$ will be represented in the examples, in those positions in which overt subjects are not licensed. We will study the distribution of null subjects [e] and controlled non-overt subjects PRO from section 3 on.

ix As with nominal arguments (i), the absolutive can be realized as a partitive with nominalizations

(ii) (cf. Artiagoitia 2003a):

(i) Hemen ez dago lan-ik.

here NEG is work-PART 
'There is no work here.'

(ii)Hemen ez dago lan egi-te-rik.

here NEG is work do-TZE-PART

'There is no way to work here (lit. There is no working here).'

$x$-tzeko and -tzera are synchronically single morphemes, although historically they seem be constituted by the morpheme -tze- plus the genitive postposition - $k o$ and the allative -ra respectively (Artiagoitia 2003a).

xi Actually, overt subjects are licensed in TZERA infinitives and in certain TZEN

infinitives, but only under certain strict conditions: they must be (i) pronouns, (ii)

focused and (iii) controlled. I will abstrac

$\mathrm{t}$ away from this phenomenon in this paper

(cf. Duguine (2012) for a discussion).

xii There are some points of dialectal variation. Artiagoitia (2003a) notes that in Western dialects, the complements of movement verbs are formed as TZEN complements, instead of TZERA complements, as we described above, and that tough constructions are formed with TZEN in Central and Western dialects and with TZEKO in the other dialects.

xiii Arteatx (this volume) argues that TZEN complements of perception verbs do project a subject, but that it always raises to the main clause where it participates in Case and Agree relations. This would explain why overt subjects cannot be licensed within these infinitival clauses in examples like (18).

${ }^{\text {xiv }}$ For ease of exposition, I will use the symbol 'PRO' to represent silent controlled subjects throughout this paper. However, note that nothing crucial hinges on the analysis of these subjects as either PRO elements or 'traces' of moved DPs as in Hornstein (1999) (cf. also Boeckx, Hornstein \& Nunes (2010) and references given therein).

xv I will not distinguish Exhaustive Control and Partial Control. I will group them together, represent them as 'PROs', and refer to them as instances of Obligatory Control. On the distinction between Exhaustive Control and Partial Control in Basque, $c f$. San Martin (2004).

${ }^{x v i}$ Actually, it has been argued that they both are the result of movements to Case-positions ( $c f$. Boeckx, Hornstein \& Nunes (2010) and references given therein).

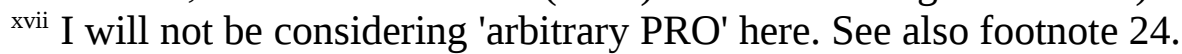

${ }^{\text {xviii }}$ As we will see in section 5, under certain circumstances, the subject cannot be dropped in argumental infinitives. See also San Martin (2008, this volume), where it is argued that the non-overt subjects in argumental infinitives involve Partial Control (a type of obligatorily controlled PRO) rather than null arguments (pros). I delay the discussion of these cases until section 5 given that for the time being, what is interesting for us is that null subjects are actually licensed in argumental infinitives, unlike in other types of TZE infinitives.

Note also that the non-overt subject can have an arbitrary reading in these examples.

${ }^{\text {xix }}$ Certain speakers accept the pro reading when it is forced by the context (Pablo Albizu, p.c.). Also, Ortiz de Urbina (1989: 185) gives the following example:

(i) [Etxe-tik atera-tze-a-n] konturatu da Jon giltzak barruan zeudela. house-from go out-TZE-D-INE realize AUX Jon keys inside AUX-that

'Upon (my/Peter's/his/...) going out of the house, Jon realized that the keys were inside.'

xx See Goenaga (1984) for a first study of the pro/PRO alternations in Basque infinitives. He states that pro subjects are overall licit in nominalizations, except when the semantics of the selecting main verb require a control construction.

${ }^{x x i}$ I assume that structural Case assignment is the result of an Agree operation between a functional head and a DP with an unvalued Case-feature (cf. Chomsky 2000). As such, DPs with structural Case are to be opposed to both DPs with inherent Case or to DPs with no Case. For a more detailed discussion of the nature of structural Case with regards to its effect on pro-drop, see Duguine (2012).

xxii The licensing condition in (32) also predicts that, cross-linguistically, null arguments will be 
licensed in and only in argument positions in which structural Case is assigned. Because of space limitations, I do not discuss this any further here; I refer the reader to Duguine (2012: Chapter 4) for a detailed discussion and arguments in favor of this proposal.

xxiii Actually, Arteatx (this volume) argues convincingly that TZEN complements selected by perception verbs are smaller than TPs. It remains to be seen whether this is the case of all TZEN complements, and whether this is also the case of TZERA complements. As for infinitival adjuncts and complements of directive verbs, in Duguine (2012) I argue that they do project a TP.

${ }^{\text {xxiv }}$ But note that if the subject of the infinitival raises to the higher clause and is assigned structural Case there, then it can be null. This would be the case of the subject of TZEN complements selected by perception verbs if, as argued in Arteatx (this volume), these raise to the higher inflected clause:

(i) $\mathrm{Zu}_{\mathrm{i}} /[\mathrm{e}]_{\mathrm{i}} \quad\left[{ }_{\perp}\right.$ i iris-ten $] \quad$ ikusi zaitut.

you.ABS arrive-TZEN see AUX.2sgABS.1sgERG

'I saw you arriving.'

${ }^{x x v}$ As said above, there are cases in which the subjects of argumental infinitives are controlled non-overt subjects. In these cases, they have the properties of OC PRO. See section 5 below, and San Martin (this volume).

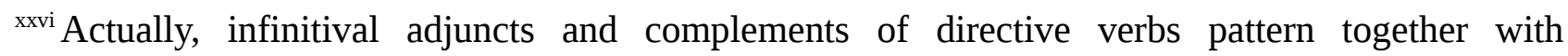
argumental infinitives and finite clauses in one test: the non-overt subject can have arbitrary reference if there is no controller DP:

(i) $[\Delta$ lan egi-te-a $]$ garrantzitsua da. work do-TZE-D.ABS important is

'It is important to work.'

(ii) $[\Delta$ lan egi-teko] agindu du. work do-TZEKO order AUX

'She ordered to work.'

(iii) $[\Delta$ lan egi-te-a-n] denbora azkar doa. work do-TZE-D-INE time quickly goes

'When working, time flies.'

I will not discuss these cases here. The reader is referred to Duguine (2012), where I argue that they do not constitute a counterexample to the point made here.

${ }^{\text {xxvii }}$ All the English examples in this section are taken from Hornstein (1999).

${ }^{x x v i i i} C f$. also San Martin (2004) on split antecedents. She shows that non-overt subjects in argumental infinitives can have a split antecedent (i), while subjects in TZEN complements cannot (ii):

(i) $\mathrm{Nik}_{\mathrm{i}} \quad$ Mariari $_{\mathrm{j}}\left[[\mathrm{e}]_{\mathrm{i}+\mathrm{j}}\right.$ elkarrekin joa-te-a] erabaki dudala esan diot. I.ERG Maria.DAT together go-TZE-D.ABS decide AUX.that say AUX

'I have told Mary that I have decided to go together.'

(ii)* Nik $_{\mathrm{i}}$ Mariari $_{\mathrm{j}} \quad\left[\mathrm{PRO}_{*_{\mathrm{i}+\mathrm{j}}}\right.$ elkarrekin joa-ten] saiatu naizela esan diot. I.ERG Maria.DAT together go-TZEN try AUX.that say AUX

Lit. 'I have told Mary that I have tried to go together.'

${ }^{x x i x}$ The use of the quantifier oro is nowadays limited to eastern dialects (cf. Trask 2003).

${ }^{x x x}$ On the DP in Basque, $c f$. Artiagoitia 1997, Trask 2003, Etxeberria 2005 a.o., as well as the articles included in this volume.

${ }^{x x x i}$ Even if the absolutive case is null, we can see that it is present on both (94b) and (94c), because the subjects gizona 'the man' and gizon eta emazteak 'the men and women' are headed by the determiner $-a$, which is not the case in (95b).

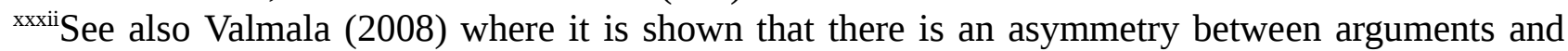
adjuncts with respect to the licensing of floating quantifiers.

xxxiii Unfortunately, this cannot be tested with infinitival adjuncts, given that they are by themselves strong islands in Basque. Indeed, as illustrated in (i) with the extraction of the object DP, 
arguments cannot extract from adjuncts:
(i) *Nor haserre zara
who angry AUX.2sgABS
[PRO _ ikus-te-a-gatik]?
'*Who are you angry because you saw?'

${ }^{x x x i v}(87)$ is grammatical when the wh-adverb is interpreted as modifying the main clause.

${ }^{x x x v}$ Note also that Postal (1998) shows that in English, DPs in 'antipronominal contexts' -contexts which are incompatible with definite pronouns- cannot be subject to extraction from weak islands. It would be interesting to see whether there is a one-to-one correspondence between the contexts in which structural Case is not assigned and these antiprononimal contexts.

${ }^{\text {xxxvi }}$ It is not my intention to claim that wh-extraction is subject to a general constraint on structural Case assignment, or that the weak islands phenomenon can be reduced to a similar constraint. It seems however that at least in the latter case, it could be part of the explanation.

xxxvii The parallel with English is also interesting here: like complements of directive verbs in Basque, English clausal gerunds usually freely alternate between having an overt subjects vs. an OC null subject. The exception is constituted by clausal gerunds in subject position, where overt subjects alternate with NOC null subjects (cf. Pires 2007, and references given therein). See Duguine (2012) for an analysis of the English data in terms of the Licensing condition on pro-drop.

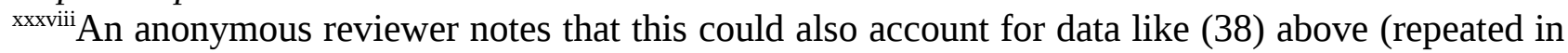
(i)), where an overt subject is licensed inside an infinitive which is the complement of the main verb.

(i) Susan preferred [John/him being late for dinner].

The difference with regards to Basque argumental infinitives would be that in English, the subject surfaces with objective case (which is nominative in English, and absolutive in Basque) and not subjective case (nominative in English, ergative or absolutive in Basque):

(ii) [Haurr-ek liburuak irakurtze-a-k] pozten gaitu.

children-ERG books.ABS read-TZE-D-ERG delight AUX.1plABS.3sgERG

'It delights us that the children read books.'

However, I would rather believe that (i) is similar to non-argumental infinitives of Basque (iv) (i.e. adjuncts and TZEKO complements). That is: no structural Case is assigned to the subject inside the infinitive, and non-overt subjects are controlled:

(iii) Susan $_{\mathrm{i}}$ preferred [John/him/ $/ \Delta_{\mathrm{i} / \mathrm{j}_{\mathrm{j}}}$ being late for dinner].

(iv) $\left[\mathrm{Zuk} / \Delta_{\mathrm{i} / *_{\mathrm{j}}}\right.$ kanta-tze-a-n], nik $\mathrm{i}_{\mathrm{i}}$ arazo guztiak ahazten ditut. you.ERG sing-TZE-D-INE I.ERG problem all.ABS forget AUX

'When you/I sing, I forget all my problems.'

${ }^{x x x i x} \mathrm{~A}$ similar hypothesis on the role of morphological case in the licensing of overt subjects in nominalizations is entertained in Ortiz de Urbina (1989).

xl See Sundaresan \& McFadden (2009) for a related idea on Tamil and other languages.

xli This special feature of North-Eastern varieties of Basque is one of the reasons that leads linguists to analyze TZE infinitival clauses as nominalizations (cf. Goenaga 1984).

xlii As noted in Heath (1972), the genitive objects are more deviant in infinitival adjuncts headed by the comitative or inessive postpositions in the Navarro-Labourdin dialect of North-Eastern varieties of Basque (but are fine in the Souletin dialect):
(i) ??[Ator honen janz-te-a-n/-rekin] eder sen
shirt this.GEN wear-TZE-D-INE/-with beautiful feel
Navarro-Labourdin

'When wearing this shirt, I feel beautiful.'

There could be a correlation between the deviance of this example with a genitive object and the presence of the article '- $a$ ' on the nominalization. However, this would be a little bit surprising, given that argumental infinitives all bear an article and still allow genitive objects. The source of these contrasts remains to be investigated.

xliii It remains to be seen whether argumental infinitives can be of type A2, that is, whether there are cases in which they license an overt subject but do not assign structural Case to it. 
${ }^{x l i v}$ Argumental infinitives are not the only infinitives that can have diverging internal structures: $c f$. the analysis of modal complements in Etxepare \& Uribe-Etxebarria (2009). 